\title{
ZUSES
}

NATIONAL WATER-QUALITY ASSESSMENT PROGRAM

$\operatorname{dump}$

DEPOSITORY

\section{Trace Elements in Bed Sediments and Biota from Streams in the Santee River Basin and Coastal Drainages, North and South Carolina, 1995-97}

U.S. Geological Survey

Water-Resources Investigations Report 99-4179
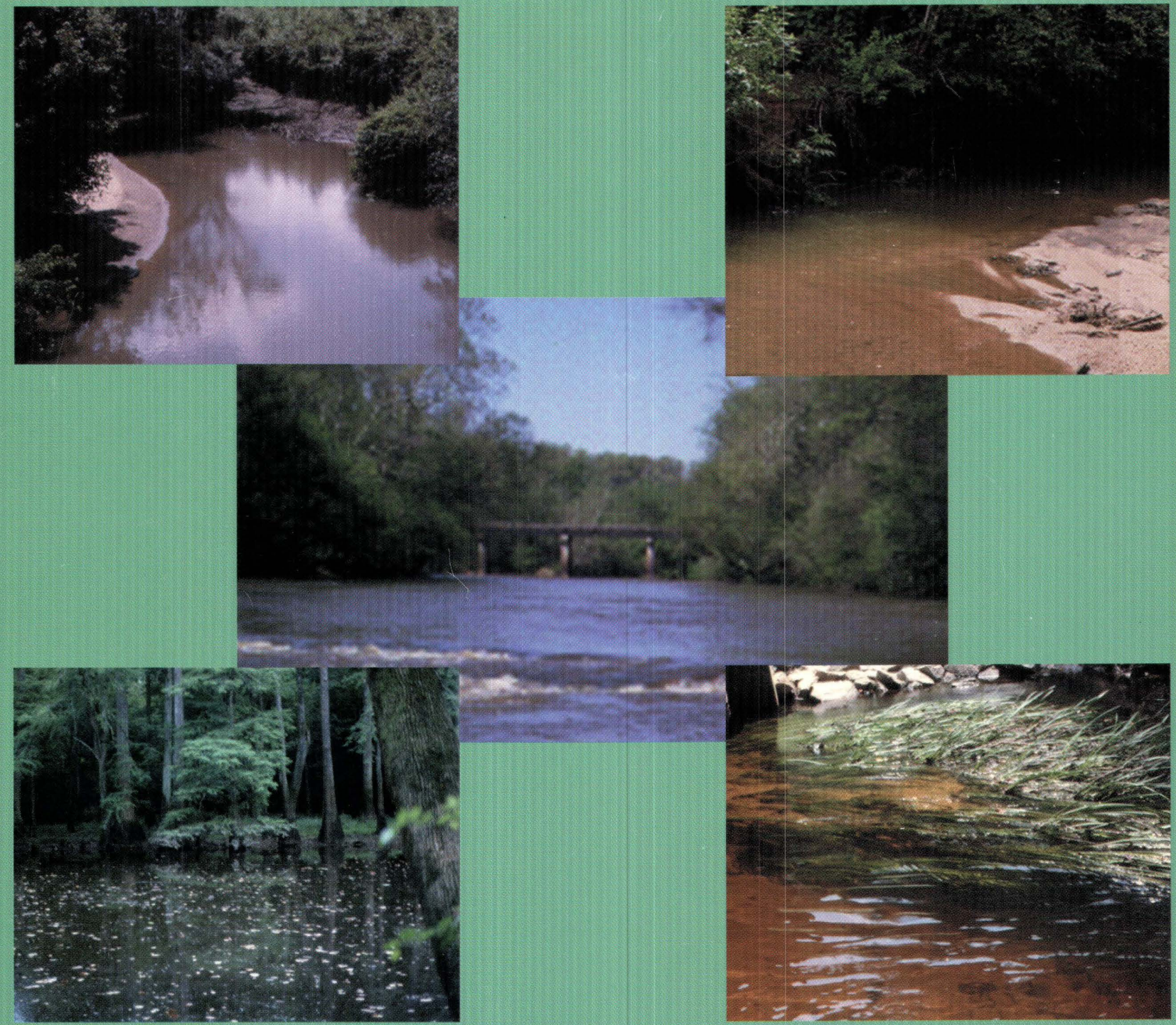

U.S. Department of the Interior

U. S. Geological Survey 


\section{Cover photographs:}

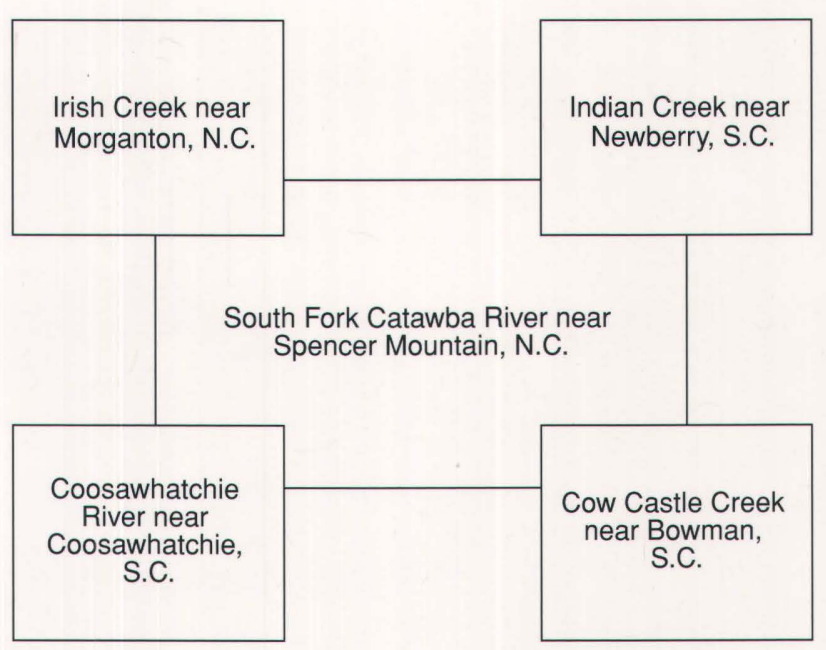




\section{Trace Elements in Bed Sediments and Biota from Streams in the Santee River Basin and Coastal Drainages, North and South Carolina, 1995-97}

By Thomas A. Abrahamsen

U.S. GEOLOGICAL SURVEY

Water-Resources Investigations Report 99-4179

Prepared as part of the

NATIONAL WATER-QUALITY ASSESSMENT PROGRAM

Columbia, South Carolina

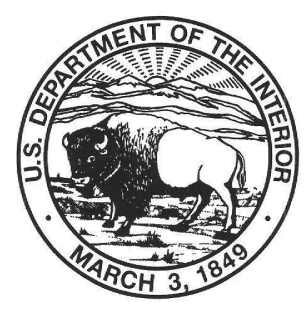




\title{
U.S. DEPARTMENT OF THE INTERIOR BRUCE BABBITT, Secretary
}

\author{
U.S. GEOLOGICAL SURVEY
}

Charles G. Groat, Director

The use of firm, trade, and brand names in this report is for identification purposes only and does not constitute endorsement by the U.S. Geological Survey.

For additional information write to:

District Chief

U.S. Geological Survey

720 Gracern Road, Suite 129

Columbia, SC 29210
Copies of this report can be purchased from:

U.S. Geological Survey Information Services Box 25286, Denver Federal Center Denver, CO 80225 


\section{FOREWORD}

The mission of the U.S. Geological Survey (USGS) is to assess the quantity and quality of the earth resources of the Nation and to provide information that will assist resource managers and policymakers at Federal, State, and local levels in making sound decisions. Assessment of water-quality conditions and trends is an important part of this overall mission.

One of the greatest challenges faced by waterresources scientists is acquiring reliable information that will guide the use and protection of the Nation's water resources. That challenge is being addressed by Federal, State, interstate, and local water-resource agencies and by many academic institutions. These organizations are collecting water-quality data for a host of purposes that include: compliance with permits and water-supply standards; development of remediation plans for a specific contamination problem; operational decisions on industrial, wastewater, or water-supply facilities; and research on factors that affect water quality. An additional need for water-quality information is to provide a basis on which regional and national-level policy decisions can be based. Wise decisions must be based on sound information. As a society we need to know whether certain types of water-quality problems are isolated or ubiquitous, whether there are significant differences in conditions among regions, whether the conditions are changing over time, and why these conditions change from place to place and over time. The information can be used to help determine the efficacy of existing water-quality policies and to help analysts determine the need for and likely consequences of new policies.

To address these needs, the Congress appropriated funds in 1986 for the USGS to begin a pilot program in seven project areas to develop and refine the National Water-Quality Assessment (NAWQA) Program. In 1991, the USGS began full implementation of the program. The NAWQA Program builds upon an existing base of water-quality studies of the USGS, as well as those of other Federal, State, and local agencies. The objectives of the NAWQA Program are to:

- Describe current water-quality conditions for a large part of the Nation's freshwater streams, rivers, and aquifers.
- Describe how water quality is changing over time.

- Improve understanding of the primary natural and human factors that affect water-quality conditions.

This information will help support the development and evaluation of management, regulatory, and monitoring decisions by other Federal, State, and local agencies to protect, use, and enhance water resources.

The goals of the NAWQA Program are being achieved through ongoing and proposed investigations of 60 of the Nation's most important river basins and aquifer systems, which are referred to as study units. These study units are distributed throughout the Nation and cover a diversity of hydrogeologic settings. More than two-thirds of the Nation's freshwater use occurs within the 60 study units and more than twothirds of the people served by public water-supply systems live within their boundaries.

National synthesis of data analysis, based on aggregation of comparable information obtained from the study units, is a major component of the program. This effort focuses on selected water-quality topics using nationally consistent information. Comparative studies will explain differences and similarities in observed water-quality conditions among study areas and will identify changes and trends and their causes. The first topics addressed by the national synthesis are pesticides, nutrients, volatile organic compounds, and aquatic biology. Discussions on these and other waterquality topics will be published in periodic summaries of the quality of the Nation's ground and surface water as the information becomes available.

This report is an element of the comprehensive body of information developed as part of the NAWQA Program. The program depends heavily on the advice, cooperation, and information from many Federal, State, interstate, Tribal, and local agencies and the public. The assistance and suggestions of all are greatly appreciated.

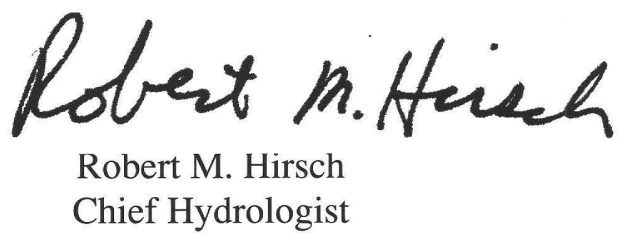





\section{CONTENTS}

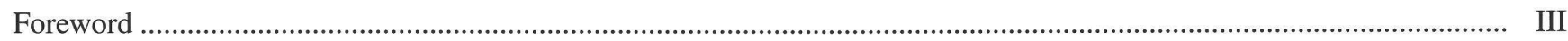

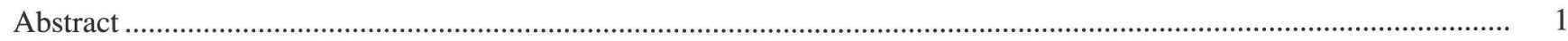

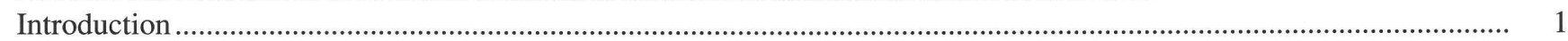

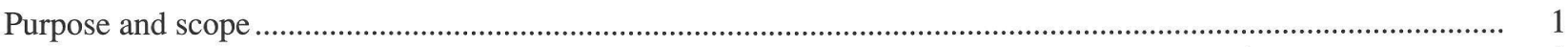

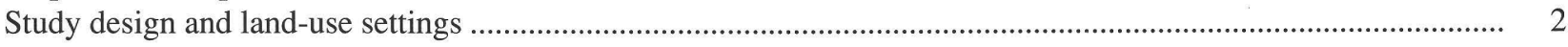

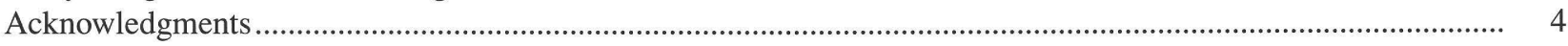

Methods.

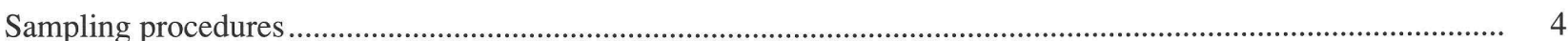

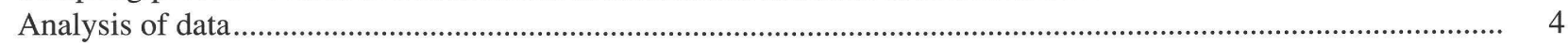

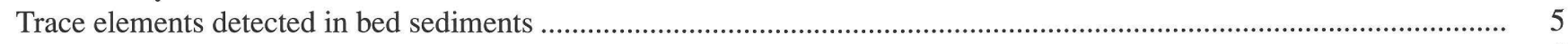

Priority pollutants ......................................................................................................................................... 5

Sediment trace-element priority-pollutant concentrations compared to criteria for the protection of aquatic life........................................................................................................................................ 7

Sediment trace-element priority-pollutant concentrations compared among land-use settings................................. 9

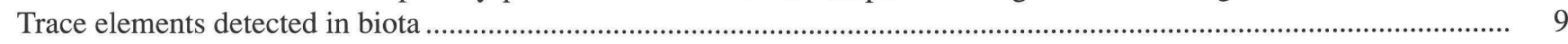

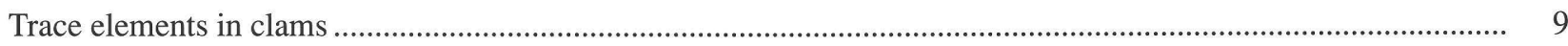

Trace elements in carp liver tissue ........................................................................................................... 11

Tissue trace-element priority-pollutant concentrations compared among land-use settings .................................... 12

Trophic-level comparisons of selected trace elements ................................................................................................. 12

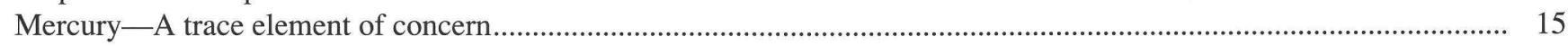

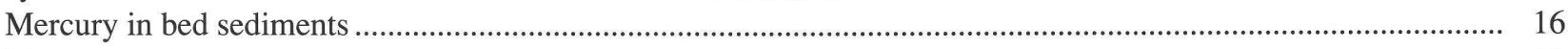

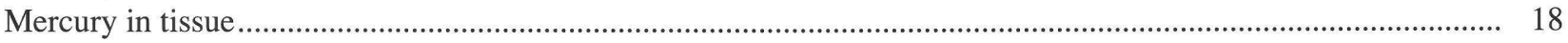

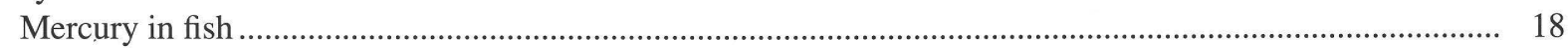

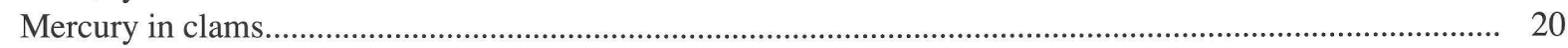

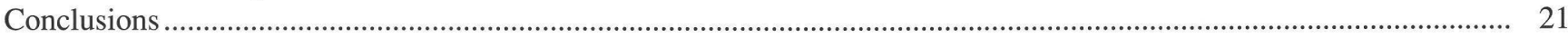

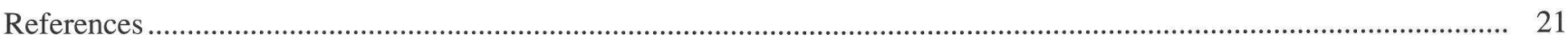

Appendixes
1. Land-use percentages for Santee River Basin and coastal drainages National Water-Quality Assessment Program sites.

2. Element concentrations in Santee River Basin and coastal drainages bed sediments and laboratory reporting limits for sediment samples .......

3. Element concentrations in Santee River Basin and coastal drainages clam tissue homogenate and laboratory reporting limits for tissue samples......

4. Element concentrations in Santee River Basin and coastal drainages carp liver tissue homogenate and laboratory reporting limits for tissue samples......

\section{FIGURES}

1. Map showing location of study sites in the Santee River Basin and coastal drainages study area.......................... 3

2-16. Graphs showing:

2. Sum of trace elements in bed sediments at each sampling site.

3. Distribution of trace-element priority pollutants in bed sediments

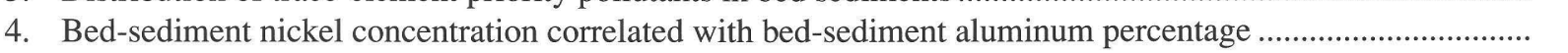

5. Lead concentrations in bed sediments, by land-use setting..................................................................

6. Distribution of trace-element priority pollutants in clams....................................................................... 10

7. Distribution of trace-element priority pollutants in carp ................................................................ 11

8. Copper concentrations in Asiatic clam tissues, by land-use setting ............................................................... 12 
9. Partitioning of trace-element priority pollutants among bed sediments, Asiatic clams, and carp from six streams in the Santee River Basin and coastal drainages study area ............................................. 13

10. Arsenic, chromium, lead, and nickel concentrations among bed sediments, Asiatic clams, and carp .............. 14

11. Cadmium, copper, selenium, and zinc concentrations among bed sediments, Asiatic clams, and carp............ 15

12. Maximum and median bed-sediment mercury concentrations among southeastern National Water-Quality Assessment Program study areas

13. Santee River Basin and coastal drainages bed-sediment median mercury concentration compared with those of the 1991 National Water-Quality Assessment Program study areas

14. Ratio of carp liver tissue mercury concentration to bed-sediment mercury concentration in six streams of the Santee River Basin and coastal drainages study area.......................................................... 18

15. Mercury concentrations in carp liver tissue ....................................................................................... 19

16. Mercury concentrations in Asiatic clam tissue collected from streams in South Carolina as part of the National Water-Quality Assessment Program

\section{TABLES}

1. Sampling sites for bed sediments and tissue trace elements in the Santee River Basin and coastal drainages study area

2. Santee River Basin and coastal drainages median trace-element priority-pollutant concentrations compared to national median values

3. Trace-element priority-pollutant concentrations in Santee River Basin and coastal drainages bed-sediment samples compared to Canadian threshold effect levels

4. Selected trace-element concentrations in bed sediments from the Santee River Basin and coastal drainages study area, by ecoregion

CONVERSION FACTORS

\begin{tabular}{rcl}
\hline Multiply & By & To obtain \\
\hline mile $(\mathrm{mi})$ & 1.609 & kilometer \\
square mile $\left(\mathrm{mi}^{2}\right)$ & 2.590 & square kilometer \\
\hline
\end{tabular}

\section{ABBREVIATIONS AND ACRONYMS}

$\begin{array}{ll}\text { ANOVA } & \text { Analysis of variance } \\ \text { DHEC } & \text { South Carolina Department of Health and Environmental Control } \\ \mu \mathrm{g} / \mathrm{g} & \begin{array}{l}\text { microgram per gram } \\ \text { micrometer }\end{array} \\ \mu \mathrm{m} & \text { National Water-Quality Asssessment Program } \\ \text { NAWQA } & \text { Santee River Basin and coastal drainages } \\ \text { SANT } & \text { Sediment-quality guidelines } \\ \text { SQG } & \text { Threshold effect level } \\ \text { TEL } & \text { U.S. Geological Survey } \\ \text { USGS } & \end{array}$




\title{
Trace Elements in Bed Sediments and Biota from Streams in the Santee River Basin and Coastal Drainages, North and South Carolina, 1995-97
}

\author{
By Thomas A. Abrahamsen
}

\section{ABSTRACT}

Bed-sediment and tissue samples were collected and analyzed for the presence of trace elements from 25 sites in the Santee River Basin and coastal drainages study area during 1995-97 as part of the U.S. Geological Survey's National Water-Quality Assessment Program. Sediment trace-element priority-pollutant concentrations were compared among streams draining watersheds with different land-use settings. Bed sediments from streams draining urban settings contained significantly higher concentrations of lead than bed sediments from streams draining predominantly forested settings, which were designated as reference settings. None of the bedsediment concentrations of trace-element priority pollutants exceeded levels considered harmful to aquatic life.

Tissue samples of Asiatic clams (Corbicula fluminea) from 18 sites in the Santee River Basin and coastal drainages study area were analyzed for the presence of selected trace-element priority pollutants. Asiatic clams from streams with watersheds dominated by urban land-use settings had significantly higher tissue concentrations of copper than those from streams in predominantly forested settings.

Mercury is of some concern in the study area because of its potential to be bioaccumulated through successive trophic levels. Advisories against fish consumption have been issued for many streams in the Middle Atlantic Coastal Plain of South Carolina because of high mercury concentrations in the filets of popular game fish. Although not directly comparable to concentrations in the filets of game fish, liver tissue from common carp (Cyprinus carpio) from the Edisto and Wateree Rivers contained mercury concentrations that exceeded the South Carolina action level of 0.5 microgram per gram (dry weight). Mercury concentration in the tissue of Asiatic clams from the Edisto River was 24 times higher than the State fish-consumption advisory level.

\section{INTRODUCTION}

The occurrence and distribution of elements in streambed sediment and biota are standard components of the U.S. Geological Survey's (USGS) National Water-Quality Assessment (NAWQA) Program. Since 1991, NAWQA Study Units have been assessing the status of trace and major elements in streams throughout the United States. The Santee River Basin and coastal drainages (SANT) Study Unit began assessment activities in 1994, as part of the NAWQA Program.

\section{Purpose and Scope}

The purposes of this report are to (1) describe the extent and concentration of elements in the bed sediments and biota from streams in the SANT study area, with emphasis on nine trace-element priority pollutants; (2) report the relation between land-use settings and the concentrations of trace-element 
priority pollutants in bed sediments and biota; and (3) report the extent of the presence of mercury in the study area. This report summarizes the analyses of bedsediment and tissue samples collected at 25 sites in the SANT study area during 1995-97.

\section{Study Design and Land-Use Settings}

The SANT study area (fig. 1) encompasses approximately 23,600 square miles $\left(\mathrm{mi}^{2}\right)$ and covers parts of western North Carolina and much of South Carolina. Parts of three ecoregions - the Blue Ridge, the Southeastern Plains, and the Middle Atlantic Coastal Plain (Omernik, 1987, 1995)—are included in the study area. A detailed description of the study area can be found in Abrahamsen and others (1997). A network of 25 sampling sites (fig. 1; table 1) was selected to characterize a variety of land-use settings and environmental conditions. Each stream was assigned to a category (table 1) based on the dominant land-use setting in the watershed (Appendix 1). Categories were forested (FOR), which served as the reference sites for the study area; agricultural (AGR); urban (URB); forest-influenced agricultural (FIA); and integrator (INT) sites. Sites were designated AGR (3 sites) or FOR (9) when 50 percent or more of the drainage basin encompassed one of those land-use settings. URB sites (2) were designated as such when the percentage of urban land use exceeded 30 percent, regardless of other land-use percentages. Sites were designated FIA (2) when forested and agricultural land

Table 1. Sampling sites for bed sediments and tissue trace elements in the Santee River Basin and coastal drainages study area

[AGR, agricultural; FIA, forest-influenced agricultural; FOR, forested; INT, integrator; URB, urban]

\begin{tabular}{|c|c|c|c|c|}
\hline Site name & $\begin{array}{c}\text { ID } \\
\text { (fig. 1) }\end{array}$ & Location & $\begin{array}{l}\text { Assigned } \\
\text { land-use } \\
\text { category }\end{array}$ & $\begin{array}{c}\text { Basin } \\
\text { area } \\
\text { (square } \\
\text { miles) }\end{array}$ \\
\hline Beaver Creek & BVR & Kershaw Co., S.C. & FOR & 25 \\
\hline Big Creek & BIG & Saluda Co., S.C. & FOR & 40 \\
\hline Brushy Creek & BRU & Greenville Co., S.C. & URB & 14 \\
\hline Cedar Creek & CE1 & Richland Co., S.C. & FOR & 20 \\
\hline Cedar Creek near Wise Lake & CE2 & Richland Co., S.C. & FOR & 71 \\
\hline Congaree River at Columbia-left bank & CONL & Columbia, S.C. & INT & 7,850 \\
\hline Congaree River at Columbia_right bank & CONR & Columbia, S.C. & INT & 7,850 \\
\hline Congaree River at Highway 601 & $\mathrm{CO} 2$ & Richland Co., S.C. & INT & 8,516 \\
\hline Coosawhatchie River & $\mathrm{COO}$ & Jasper Co., S.C. & INT & 391 \\
\hline Cow Castle Creek & COW & Orangeburg Co., S.C. & FIA & 23 \\
\hline Edisto River & EDI & Dorchester Co., S.C. & INT & 2,730 \\
\hline Georges Creek & GEO & Barnwell Co., S.C. & AGR & 20 \\
\hline Gills Creek & GIL & Columbia, S.C. & URB & 60 \\
\hline Indian Creek, N.C. & INN & Lincoln Co., N.C. & AGR & 65 \\
\hline Indian Creek, S.C. & INS & Newberry Co., S.C. & FOR & 50 \\
\hline Irish Creek & IRI & Burke Co., N.C. & FOR & 10 \\
\hline Jacob Fork & JAC & Burke Co., N.C. & FOR & 26 \\
\hline Long Creek & LON & Gaston Co., N.C. & INT & 61 \\
\hline McTier Creek & MCT & Aiken Co., S.C. & FOR & 18 \\
\hline Myers Creek & MYE & Richland Co., S.C. & FIA & 32 \\
\hline Saluda River & SAL & Columbia, S.C. & INT & 2,520 \\
\hline Santee River & SAN & Calhoun Co., S.C. & INT & 14,100 \\
\hline Shaw Creek & SHA & Edgefield Co., S.C. & AGR & 12 \\
\hline South Fork Catawba River & CAT & Gaston Co., N.C. & INT & 628 \\
\hline Toms Creek & TOM & Richland Co., S.C. & FOR & 39 \\
\hline Wateree River & WAT & Richland Co., S.C. & INT & 5,070 \\
\hline
\end{tabular}




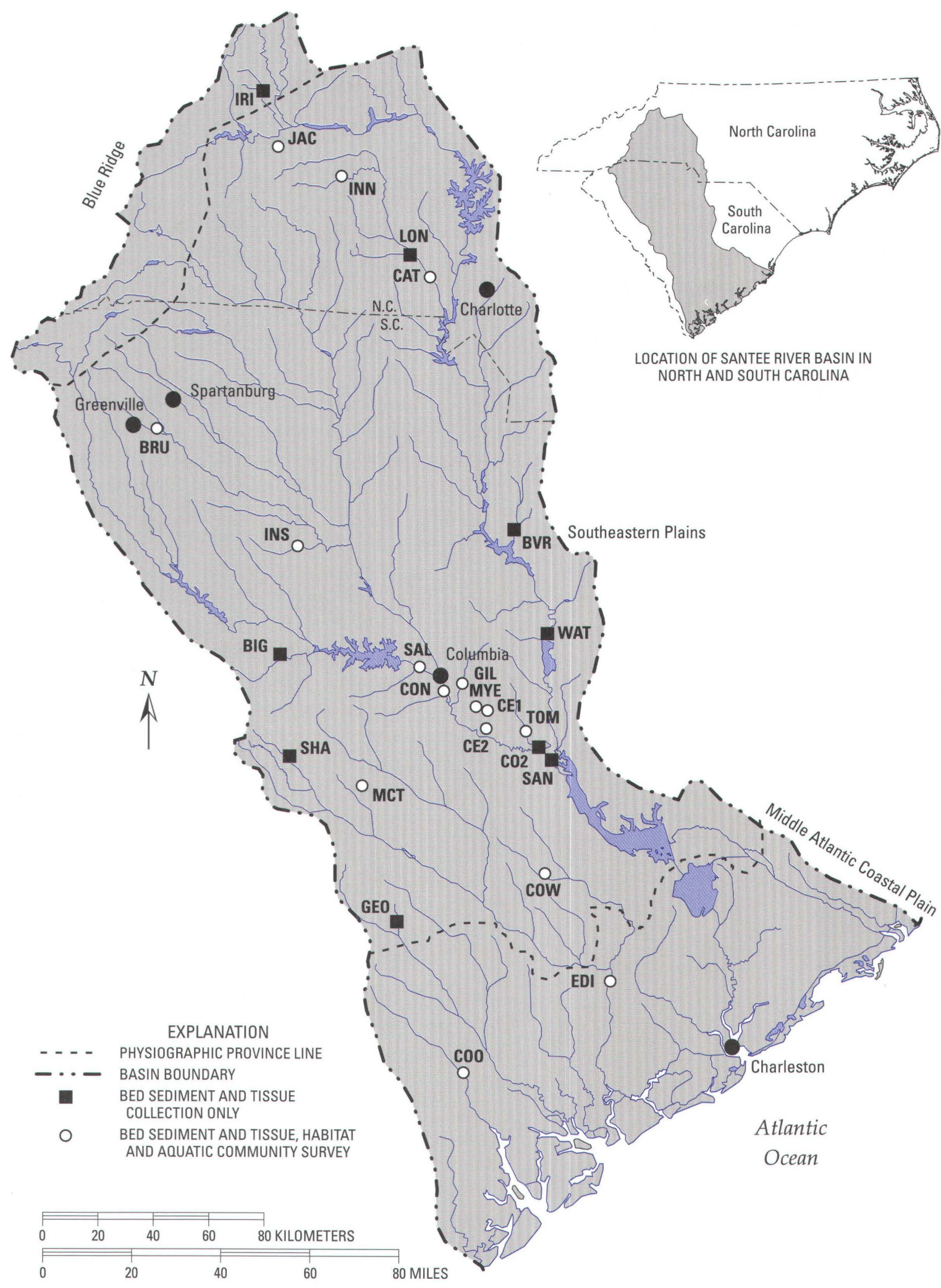

Figure 1. Location of study sites in the Santee River Basin and coastal drainages study area. (Site abbreviations are explained in table 1.) 
uses were each in excess of 30 percent, and when urban land use was less than 30 percent of the total drainage basin upstream from the sample site. Nine sites were designated INT sites, which are assumed to combine the effects of several land-use settings (table 1).

Bed-sediment and tissue samples were collected by following procedures specified by NAWQA protocols (Crawford and Luoma, 1993; Shelton and Capel, 1994). Asiatic clams (Corbicula fluminea) and the common carp (Cyprinus carpio) were selected from a national target taxon list as tissue sources. Clams are bottom-dwelling filter feeders with the ability to accumulate trace elements from the environment (Rodgers and others, 1979; Crawford and Luoma, 1993). The Asiatic clam is a preferred sampling medium because it has a rapid rate of growth and higher filtration/assimilation rates than native clams (McMahon, 1991). The Asiatic clam is a primary consumer, feeding on algae and bacteria by filtering the water. Corbicula sp. have been consumed by people in parts of Asia for at least 400 years. They are considered to be a valuable, healthy food source. The extent of human consumption of these clams in the Southeastern United States is unknown. In the absence of Asiatic clams, native freshwater clams (Elliptio sp.) were collected and analyzed as an additional source of information because they occupy the same trophic level as the Asiatic clam. If both Asiatic clams and native clams were present, individuals of each species were collected for comparative analyses; however, the data for each species were not combined because the relation between them regarding their abilities to bioaccumulate trace elements has not been established.

The carp was selected for sampling because it represents the secondary consumer trophic level. Carp are bottom feeders that prey on clams and other benthic organisms and, consequently, spend much time in close association with bed sediments (McMahon, 1991; Rohde and others, 1994).

\section{Acknowledgments}

The author expresses appreciation to the following individuals and agencies for providing information, assisting during field sampling, or reviewing the draft of this report: David Chestnut, South Carolina Department of Health and Environmental Control; Dr. Michael Lema, Midlands Technical College; Leslie Jeffcoate, Riverbanks Zoo; and the following USGS Volunteers in Science:
Brandon Falls, Kim Gundler, Kimberley Norris-Jones, Jon Lee, Jon Marr, and Chris Shupe, all of Columbia, S.C.

\section{METHODS}

The field-collection and assessment methods used in this study follow standard NAWQA protocols (Crawford and Luoma, 1993; Fishman, 1993; Shelton and Capel, 1994; Hoffman,1996). Unless specifically noted in this report, no deviation from the protocols occurred.

\section{Sampling Procedures}

Bed-sediment samples were collected from 25 sites, and tissue samples were collected from 24 sites in the SANT study area. Bed-sediment samples were collected from the top few centimeters of streambeds, within depositional zones, and wet-sieved to provide a less than 63-micrometer $(\mu \mathrm{m})$ fraction for traceelement analyses (Shelton and Capel, 1994). Tissue samples were collected as live, whole Asiatic clams; live, whole native freshwater clams; and common carp livers. Carp liver samples were excised in the field and frozen with dry ice. Several tissue or sediment subsamples from each site were composited into representative samples and were sent to the USGS National Water Quality Laboratory in Denver, Colo., for analyses of elements and organic compounds. Analytical methods for bed sediments are described in Fishman (1993) and for tissue, in Hoffman (1996).

\section{Analysis of Data}

Data were tested for normal distribution by using the Shapiro-Wilkes procedure followed by a one-way analysis of variance (ANOVA) with Dunnett's Test. If the data were not normally distributed, non-parametric procedures (Kruskal-Wallis ANOVA and the Wilcoxon signed data rank test) were used to determine the statistical significance of differences between groups of data. Plots of the median values were used to demonstrate the differences in sediment trace-element concentrations among land-use settings when the total number of samples was less than six $(n<6)$. Box plots were used to demonstrate differences in trace-element concentrations among samples of sediments, clams, and fish, when the number of samples was greater than five $(n>5)$. Unless otherwise noted, the terms 
"significantly lower than" and "significantly higher than" are in reference to an alpha level of 0.05 $(\alpha=0.05)$.

\section{TRACE ELEMENTS DETECTED IN BED SEDIMENTS}

Among 43 trace and major elements for which sediment samples were analyzed, 40 were detected at one or more sampling sites. Trace elements are defined as substances that usually occur in concentrations less than 1,000 micrograms per gram $(\mu \mathrm{g} / \mathrm{g}$ ) (Forstner and Wittmann, 1979). A summation of trace-element concentrations detected in bed sediments at each site is illustrated in figure 2. Manganese concentrations in the bed sediments of Indian Creek, S.C., (INS) and the Saluda River (SAL) account for 92 percent and 83 percent, respectively, of the "trace" elements from each stream's bed sediments. The reason for the high concentrations at these sites has not been examined. Minimum, maximum, and median trace-element concentrations at all sites are listed in Appendix 2. The complete data set, including a list of all elements for which the samples were analyzed, is available on the SANT NAWQA web site at URL http://wwwsc.er. usgs.gov/nawqa/santhome.html.

\section{Priority Pollutants}

Nine trace elements (arsenic, cadmium, chromium, copper, lead, mercury, nickel, selenium, and zinc) have been classified as priority pollutants (Code of Federal Regulations, 40CFR, 1996) because they are toxic in low concentrations to aquatic organisms. The summed concentrations of the traceelement priority pollutants for each site are presented in figure 3.

Several trace-element priority pollutants were consistently dominant in streambed sediments. Zinc composed 34 percent of the sum of trace-element priority-pollutant samples from all sites, followed by chromium (27 percent), lead (16 percent), nickel (10 percent), and copper (10 percent). The dominance of these five priority pollutants may be indicative of a natural background presence.

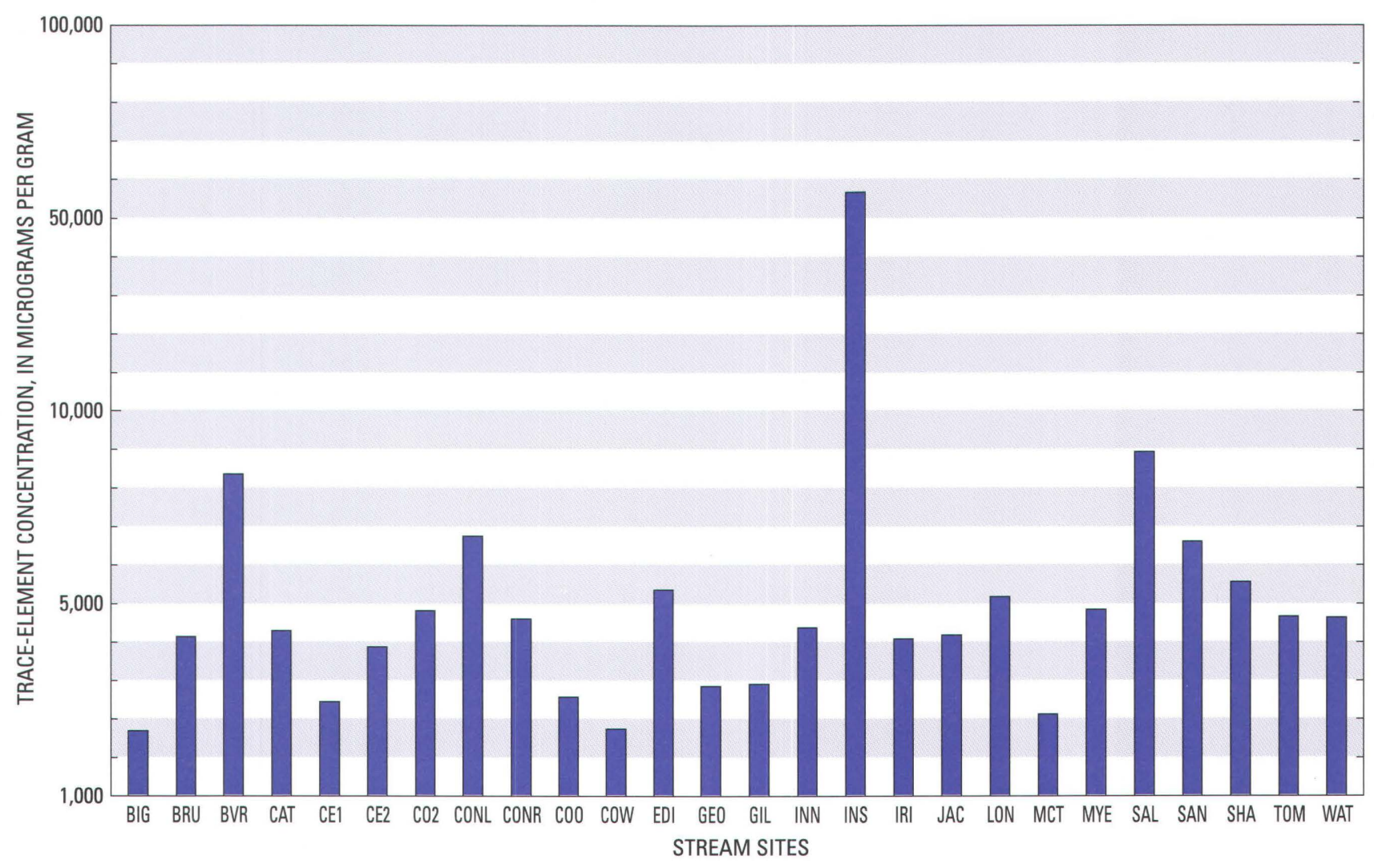

Figure 2. Sum of trace elements in bed sediments at each sampling site. (Site abbreviations are explained in table 1.) 


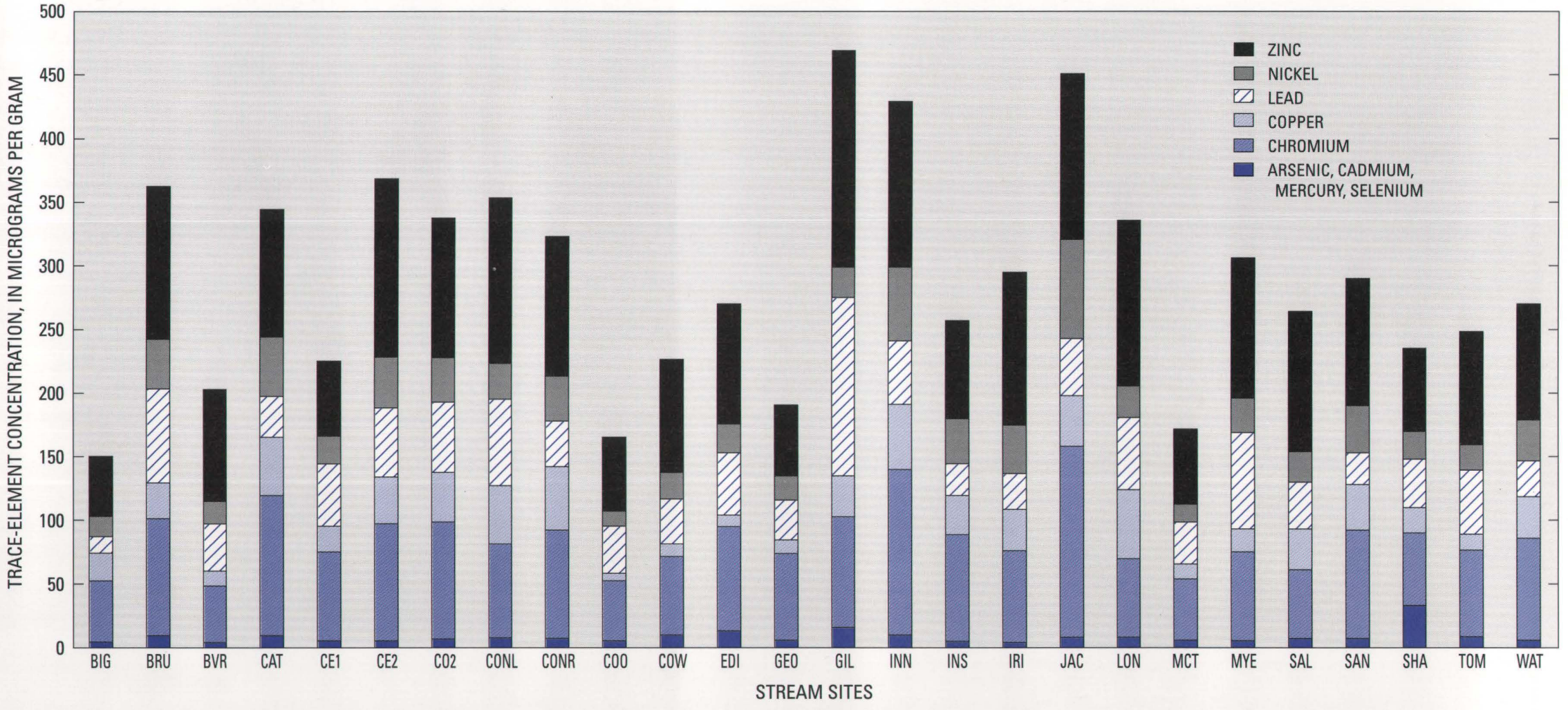

Figure 3. Distribution of trace-element priority pollutants in bed sediments. (Site abbreviations are explained in table 1.) 
The concentration of arsenic in bed sediments from Shaw Creek $(31 \mu \mathrm{g} / \mathrm{g})$ was more than twice that of any other site in the study area. Possible explanations include the use of disodium methanearsenate as a herbicide in nearby fields and the practice of spreading chicken manure as a fertilizer over pastures and hay fields in the area (Terry Mathis, Aiken County, Clemson Extension Service, oral commun., 1998). Although chicken feed is commonly fortified with substituted phenylarsonic acids known to have therapeutic and growth-promoting properties (Eisler, 1988), there was no correlation of bed-sediment arsenic concentrations with the calculated manurephosphorus and nitrogen loadings for each county (Maluk and others, 1998). Unfortunately, county manure-use data are nondiscriminatory in regard to sources of fertilizer, so any relation between chicken manure and concentrations of arsenic in bed sediments was not discernible.

The median concentrations of the nine traceelement priority pollutants in the SANT study area were similar to the median concentrations from the 1991 NAWQA study areas (Rice, 1999), as shown in table $2(\alpha=0.05)$. The concentrations of the nine trace elements appear to be relatively uniform over the range of NAWQA study areas for which data have been reported.

Table 2. Santee River Basin and coastal drainages median trace-element priority-pollutant concentrations compared to national median values

[NAWQA, National Water-Quality Assessment Program;

SANT, Santee River Basin and coastal drainages;

$\mu \mathrm{g} / \mathrm{g}$, microgram per gram; $\mathrm{n}$, number of samples]

\begin{tabular}{lcc}
\hline Element & $\begin{array}{c}\text { 1991 NAWQA } \\
\text { median* }_{(\mu \mathbf{g} / \mathbf{g})} \\
(\mathbf{n}=\mathbf{5 4 1})\end{array}$ & $\begin{array}{c}\text { SANT } \\
\text { median } \\
(\mu \mathbf{g} / \mathbf{g}) \\
(\mathbf{n}=\mathbf{2 4})\end{array}$ \\
\hline Arsenic & 6.3 & 5.7 \\
Cadmium & .4 & .3 \\
Chromium & 64 & 73 \\
Copper & 27 & 31.5 \\
Lead & 27 & 37.5 \\
Mercury & .06 & .08 \\
Nickel & 27 & 26 \\
Selenium & .7 & .9 \\
Zinc & 110 & 100 \\
\hline \multicolumn{1}{c}{$*$ Rice, 1999.} & &
\end{tabular}

\section{Sediment Trace-Element Priority-Pollutant Concentrations Compared to Criteria for the Protection of Aquatic Life}

Federal and State guidelines for the protection of aquatic life, based on bed-sediment trace-element concentrations, do not currently (1999) exist. Traceelement priority-pollutant concentrations in SANT bed-sediment samples were compared to Canadian sediment-quality guidelines (SQG) (table 3 ). The Canadian SQGs designate threshold effect levels (TELs) as concentrations below which there is little probability of adverse effects on aquatic life (Canadian Council of Ministers of the Environment, 1995). The TELs are based on bulk sediment samples, but NAWQA data are collected on that fraction of the bulk bed-sediment sample that is less than $63 \mu \mathrm{m}$ in diameter (Shelton and Capel, 1994). In general, as particle size decreases, the concentration of trace elements adsorbed in streambed materials increases. The smaller grain-size particles $(<63 \mu \mathrm{m})$, collectively, are expected to have greater surface area than the spectrum of different grain sizes in the bulk sediment samples. SANT bed-sediment trace-element data were adjusted for comparison with the TELs by multiplying

Table 3. Trace-element priority-pollutant concentrations in Santee River Basin and coastal drainages bed-sediment samples compared to Canadian threshold effect levels (Canadian Council of Ministers of the Environment, 1995)

[SANT, Santee River Basin and coastal drainages; $\mu \mathrm{g} / \mathrm{g}$, microgram per gram; $\mu \mathrm{m}$, micrometer]

\begin{tabular}{lcc}
\hline Element & $\begin{array}{c}\text { SANT } \\
\text { maximum } \\
\text { calculated* }^{*} \\
\text { concentration } \\
(\mu \mathbf{g} / \mathbf{g})\end{array}$ & $\begin{array}{c}\text { Canadian } \\
\text { threshold } \\
\text { effect level } \\
(\mu \mathbf{g} / \mathbf{g})\end{array}$ \\
\hline Arsenic & 2.31 & 5.90 \\
Cadmium & .28 & .60 \\
Chromium & 31 & 37 \\
Copper & 14.1 & 35.7 \\
Lead & 17 & 35 \\
Mercury & .12 & .17 \\
Nickel & 12 & 18 \\
Zinc & 30.2 & 123 \\
\hline
\end{tabular}

*Calculations are based on the percentage of bulk sample in which the particles were less than $63 \mu \mathrm{m}$ in diameter. 
the percentage of the bulk sample that was less than $63 \mu \mathrm{m}$ (in diameter) by the detected trace-element concentration. This calculation provides a conservative maximum estimation of the concentration of an element in a bulk sediment sample. None of the SANT samples exceeded the TELs.

Bed-sediment samples from Jacob Fork, the Catawba River, and Indian, Long, and Irish Creeks - all with headwaters in or near the Blue Ridge ecoregion-contained significantly higher concentrations of nickel than bed-sediment samples from streams in the Southeastern Plains and the Middle Atlantic Coastal Plain ecoregions (table 4). The Blue Ridge ecoregion contains rich deposits of nickel in the form of garnierite and genthite, with some veins containing up to 10 percent (Feiss and others, 1991). The median bed-sediment concentration of nickel in Blue Ridge-influenced streams was $43 \mu \mathrm{g} / \mathrm{g}$ dry weight $(n=6)$. In contrast, median concentrations of nickel in streams of the Southeastern Plains and the Middle Atlantic Coastal Plain were 29 and $21 \mu \mathrm{g} / \mathrm{g}$, respectively. The highest concentration of nickel in bed sediments $(78 \mu \mathrm{g} / \mathrm{g})$ was detected in the sample from Jacob Fork. Nickel concentrations in the SANT study area were positively correlated with aluminum (fig. 4). Since there is no reported anthropogenic source of nickel in the Jacob Fork drainage basin, this correlation
Table 4. Selected trace-element concentrations in bed sediments from the Santee River Basin and coastal drainages study area, by ecoregion

\begin{tabular}{lccc}
\hline \multicolumn{1}{c}{ Element } & $\begin{array}{c}\text { Blue } \\
\text { Ridge }\end{array}$ & $\begin{array}{c}\text { South- } \\
\text { eastern } \\
\text { Plains }\end{array}$ & $\begin{array}{c}\text { Middle } \\
\text { Atlantic } \\
\text { Coastal } \\
\text { Plain }\end{array}$ \\
\cline { 2 - 4 } & \multicolumn{3}{c}{$\begin{array}{c}\text { (median values, } \\
\text { in micrograms per gram) }\end{array}$} \\
\hline Arsenic & 6.5 & 5.5 & 3.7 \\
Chromium & 97 & 82 & 68 \\
Copper & 43 & 32 & 12 \\
Lead & 38 & 37 & 43 \\
Mercury & .07 & .07 & 1.2 \\
Nickel & 43 & 29 & 21 \\
Selenium & .7 & .8 & 1.3 \\
Zinc & 125 & 110 & 77 \\
\hline
\end{tabular}

suggests the relatively high nickel concentrations in bed sediments from the streams in the upper part of the SANT study area have a geologic origin. Aluminum concentrations in bed sediments in streams from the upper portion of the Southeastern Plain ecoregion (12 percent of the bed-sediment sample) were significantly higher than those in the Middle Atlantic Coastal Plain ecoregion (8 percent of the sample).

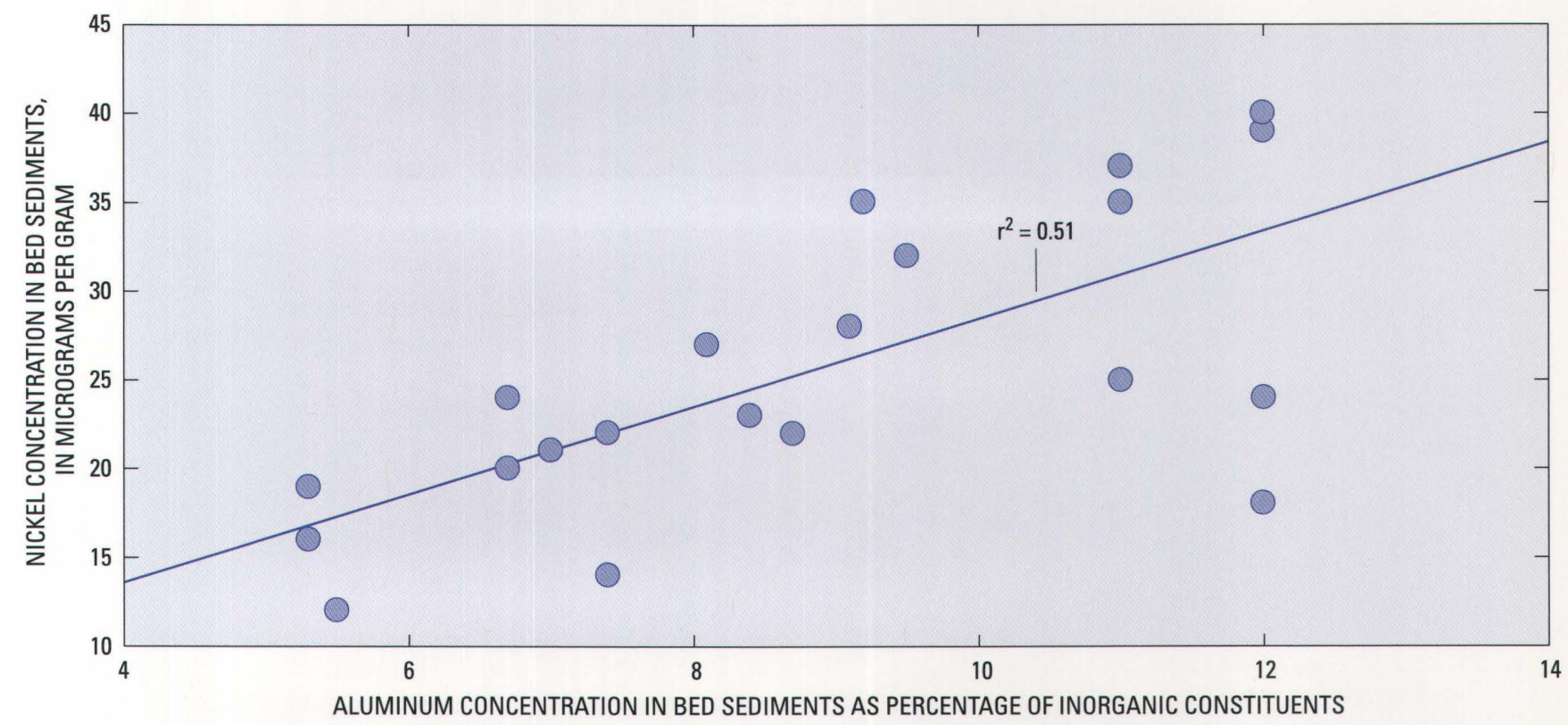

Figure 4. Bed-sediment nickel concentration correlated with bed-sediment aluminum percentage. 
In general, a decrease in the bed-sediment concentrations of arsenic, chromium, copper, nickel, and zinc occurs from the Blue Ridge ecoregion southeastward across the Southeastern Plains to the Middle Atlantic Coastal Plain. In the same direction, an increase in the bed-sediment concentrations of lead, mercury, and selenium occurs.

\section{Sediment Trace-Element Priority-Pollutant Concentrations Compared Among Land- Use Settings}

Among the land-use settings described in this report, FOR settings were considered to be the least affected by current land-use activities and, therefore, were selected to represent reference conditions.

Streams were grouped by land-use setting, and traceelement priority-pollutant concentrations from each setting were compared to the FOR group.

Concentrations of lead in bed sediments from streams in URB settings were significantly higher than concentrations of lead in bed sediments from streams in FOR settings (fig. 5). Neither AGR nor FIA settings

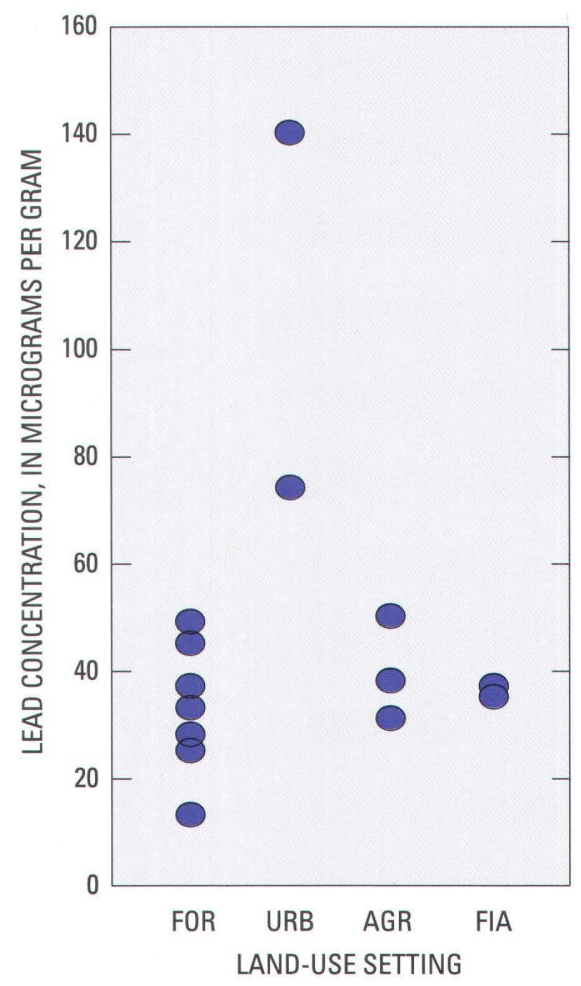

Figure 5. Lead concentrations in bed sediments, by land-use setting. (AGR, agricultural; FIA, forest-influenced agricultural; FOR, forested; URB, urban) had lead concentrations significantly greater than those in FOR settings. The range of lead concentrations in URB settings ( 74 to $140 \mu \mathrm{g} / \mathrm{g}, \mathrm{n}=2$ ) was greater than the range of lead concentrations in all other settings collectively ( 13 to $68 \mu \mathrm{g} / \mathrm{g}, \mathrm{n}=12$ ), suggesting that URB settings are more variable than other types of settings.

Trace-element priority-pollutant concentrations also were compared with percentages of land use in each stream basin sampled. A slight correlation was noted between the percentage of basin area characterized as urban and the concentration of lead in bed sediments $\left(r^{2}=0.36, \alpha=0.0014\right)$, indicating that, as urban area in a basin increases, so does the concentration of lead in bed sediments. Lead is associated with urban areas because of lead alkyls used in gasoline (Laws, 1993).

\section{TRACE ELEMENTS DETECTED IN BIOTA}

Aquatic organisms can bioaccumulate certain elements through ingestion of food or direct uptake from the water column or bed sediments, to concentrations higher than those in bed sediments or water (Laws, 1993; Brigham and others, 1998). The bioaccumulation of trace elements by aquatic organisms provides useful evidence of the presence and distribution of those elements in the aquatic environment.

\section{Trace Elements in Clams}

Tissue samples of the Asiatic clam (Corbicula fluminea), native bivalve species (Elliptio sp.), and liver tissue of the common carp (Cyprinus carpio) were analyzed for the presence of 21 elements (Appendixes 3 and 4). The most prevalent of the nine trace-element priority pollutants detected in Asiatic clam tissue were zinc and copper. Data collected for this study are similar to data collected by Pickett (1992), who also determined zinc and copper to be among the most prevalent trace elements analyzed in Asiatic clams from the Congaree and Wateree Rivers. The distribution of trace-element priority pollutants detected in Asiatic and native clam tissues is shown in figure 6 . The streams from which only native clams were collected are Cedar Creek, the Coosawhatchie River, Georges Creek, McTier Creek, and Shaw Creek. 


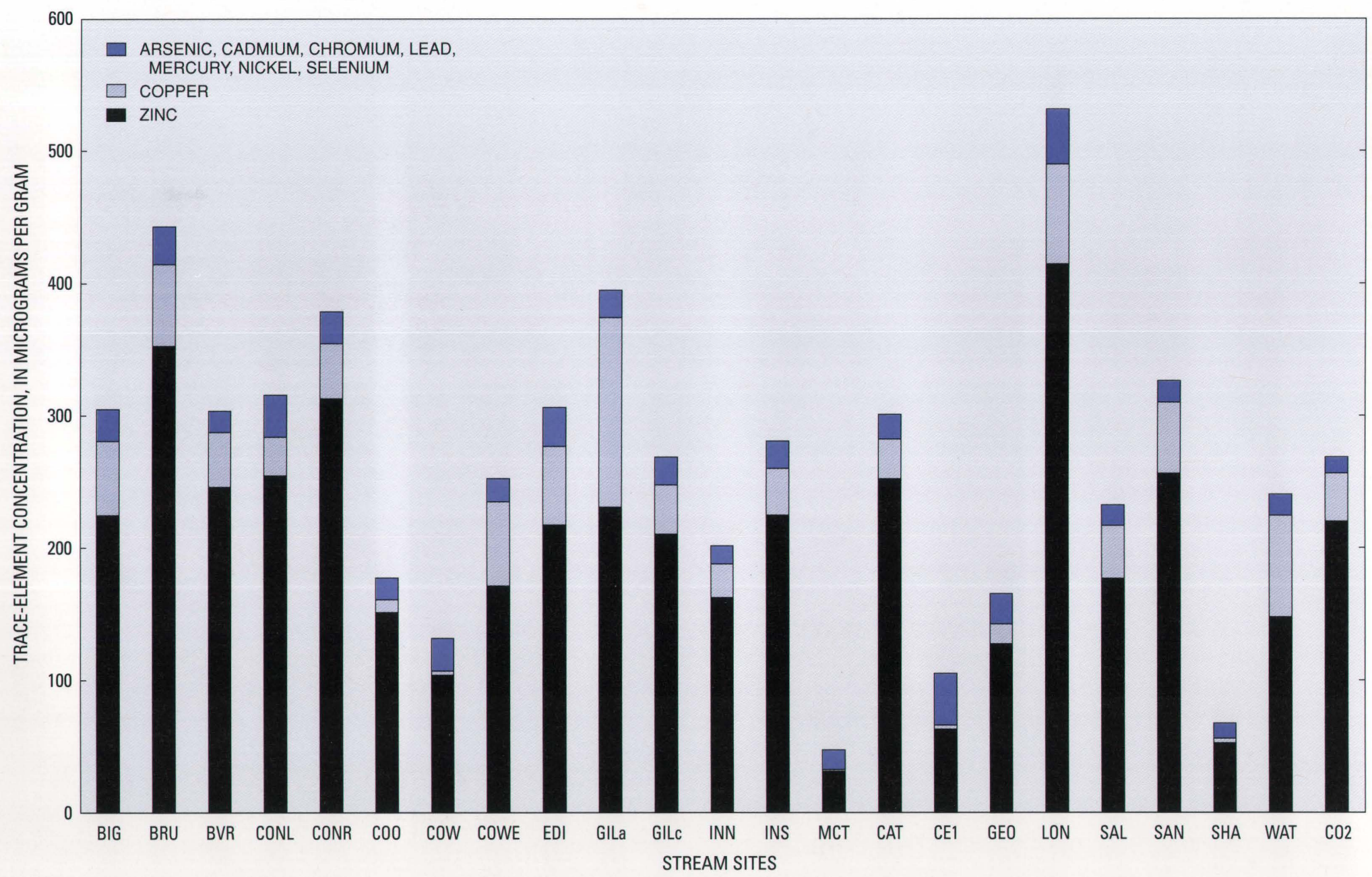

Figure 6. Distribution of trace-element priority pollutants in clams. (Site abbreviations are explained in table 1. CE1, COO, COWE, GEO, MCT, and SHA yielded native clams for analysis. COWE refers to native clams [Elliptio sp.] collected from Cow Castle Creek. GILa and GILc are different sections of GIL.) 
Native clams and Asiatic clams were collected from Cow Castle Creek.

The concentration of zinc in Asiatic clam tissues was relatively constant throughout the study area, ranging from 59 to 86 percent (median $=78$ percent) of the sum of all nine trace-element priority pollutants at each site. Copper was more variable, ranging from 2 to 36 percent (median $=14$ percent) of the sum of the nine trace-element priority pollutants at each site.

\section{Trace Elements in Carp Liver Tissue}

As in Asiatic clam tissues, zinc and copper were the most common trace-element priority pollutants in carp liver tissue (fig. 7). Zinc accounted for 77 percent of the sum of the nine trace-element priority pollutants from the six carp collection sites, and copper accounted for 22 percent. Nickel was not detected in the carp liver samples, even though it was present in bed sediments and Asiatic clams, indicating that nickel was not accumulated by the carp.

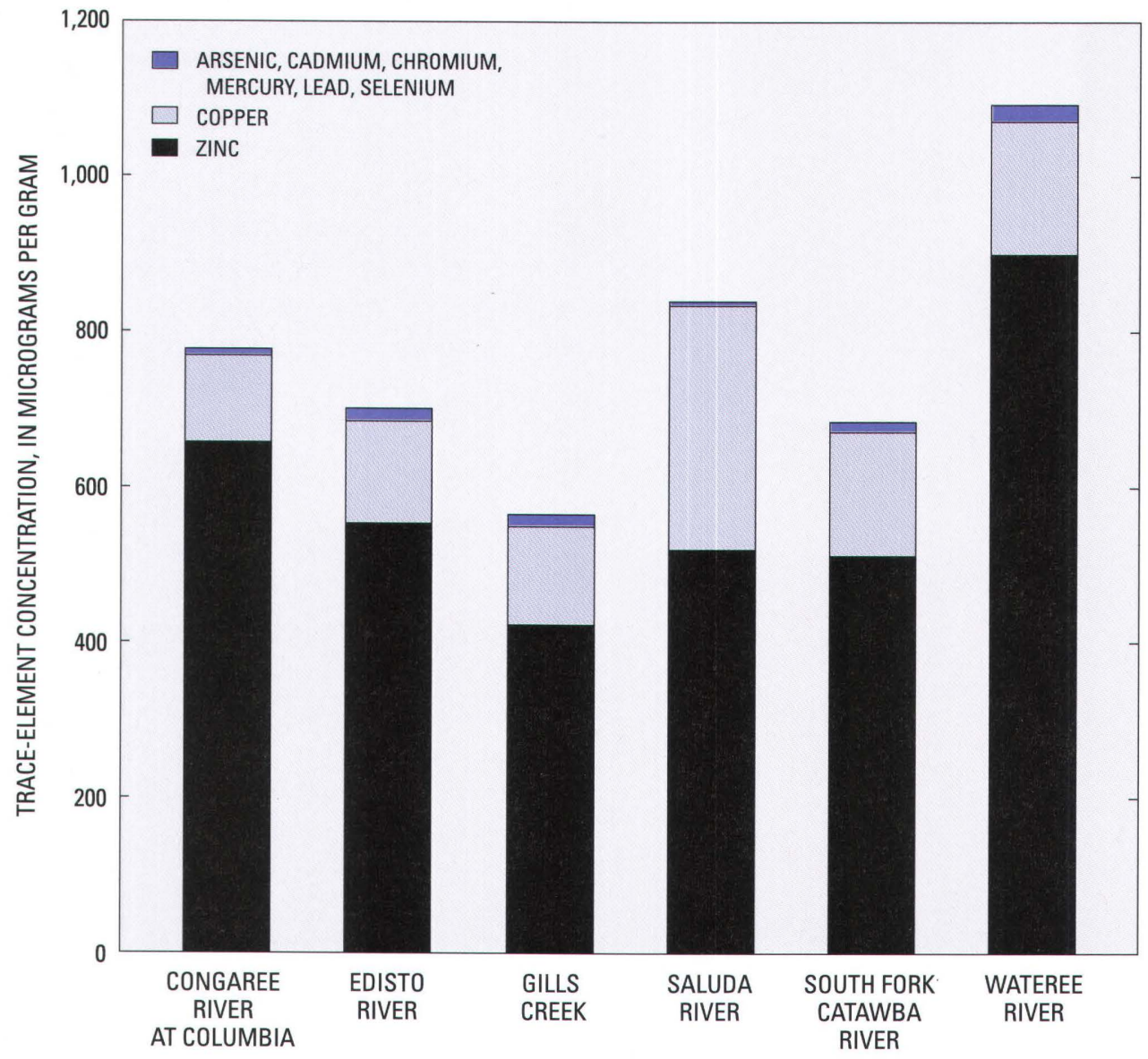

Figure 7. Distribution of trace-element priority pollutants in carp. 


\section{Tissue Trace-Element Priority-Pollutant Concentrations Compared Among Land-Use Settings}

Asiatic clams from streams in URB settings had significantly higher concentrations of copper than Asiatic clams from streams in FOR settings. Conversely, no significant difference was detected in copper concentrations in clam tissues between streams in AGR or FIA settings and streams in FOR settings. Copper in Asiatic clams from streams in URB settings was the only trace-element priority pollutant detected at significantly higher concentrations than in Asiatic clams in streams from FOR settings (fig. 8).

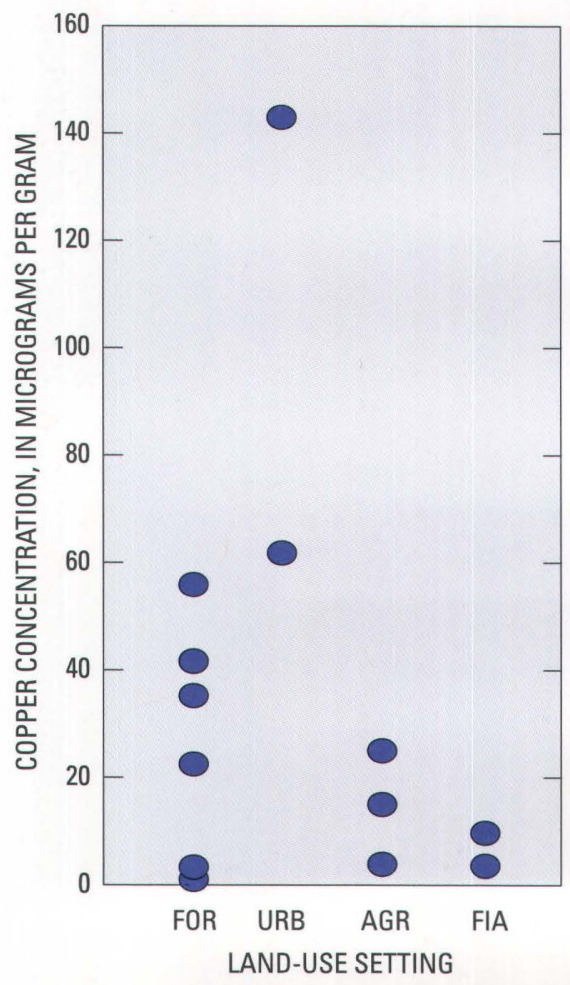

Figure 8. Copper concentrations in Asiatic clam tissues, by land-use setting. (AGR, agricultural; FIA, forest-influenced agricultural; FOR, forested; URB, urban)
Trace-element priority-pollutant concentrations in Asiatic clam tissues also were compared to land use in each stream basin. A slightly positive correlation was noted between the percentage of drainage area in URB settings and the concentration of copper in Asiatic clam tissues $\left(r^{2}=0.35, \alpha=0.0047\right)$.

\section{TROPHIC-LEVEL COMPARISONS OF SELECTED TRACE ELEMENTS}

As previously stated, aquatic organisms have the capability to assimilate elements that are present in low concentrations in bed sediments and the water column, and to bioaccumulate them to levels that may be orders of magnitude higher than ambient concentrations (Laws, 1993). Copper and zinc, for example, accumulate in liver and kidney tissues of fish (Goldstein and others, 1996). Arsenic (Elder and Mattraw, 1984), cadmium (Hemelraad and others, 1985), lead and mercury (Price and Knight, 1978), copper (Annis and Belanger, 1986), and manganese (Elder and Mattraw, 1984) are among several elements that are known to be bioaccumulated by clams.

The form and chemical state of an element influence the route and the extent of its assimilation by biota, so the bioavailability of an element is not readily predictable from its concentration in bed sediments or the water column. The route of assimilation depends on several factors. For example, the chemical activity of the free metal ions of cadmium, copper, lead, and zinc, and the oxidation states of arsenic, chromium, and selenium control the bioavailability of these metals. Biological characteristics, such as feeding rate, food selection, habitat, behavior, and digestive processes of an organism, further complicate determining the path of assimilation by a particular organism. Other important influences include the hydrodynamics of the water body, $\mathrm{pH}$, water temperature, the amount of dissolved organic material, and the concentration of suspended solids in the water column (Luoma and Fisher, 1995). An element might be present in the bed sediments of a stream yet not be in a 
form that a living organism can assimilate. Decho and Luoma (1991), for instance, reported that clams assimilate chromium more readily from ingested bacteria than from bed sediments. Frenzel (1996) reported that fish in Nebraska contained lower concentrations of arsenic and lead than were detected in bed sediments.

Carp were collected from six streams in which Asiatic clams also were collected in the SANT study area for comparison of trophic-level data. The six streams are the South Fork Catawba River (CAT), the Saluda River (SAL), the Wateree River (WAT), Gills Creek (GIL), the Congaree River (CON), and the Edisto River (EDI). The partitioning of trace-element priority pollutants among bed sediments, Asiatic clams, and carp varied significantly (fig. 9).

Asiatic clams and carp had significantly lower tissue concentrations (micrograms per gram dry

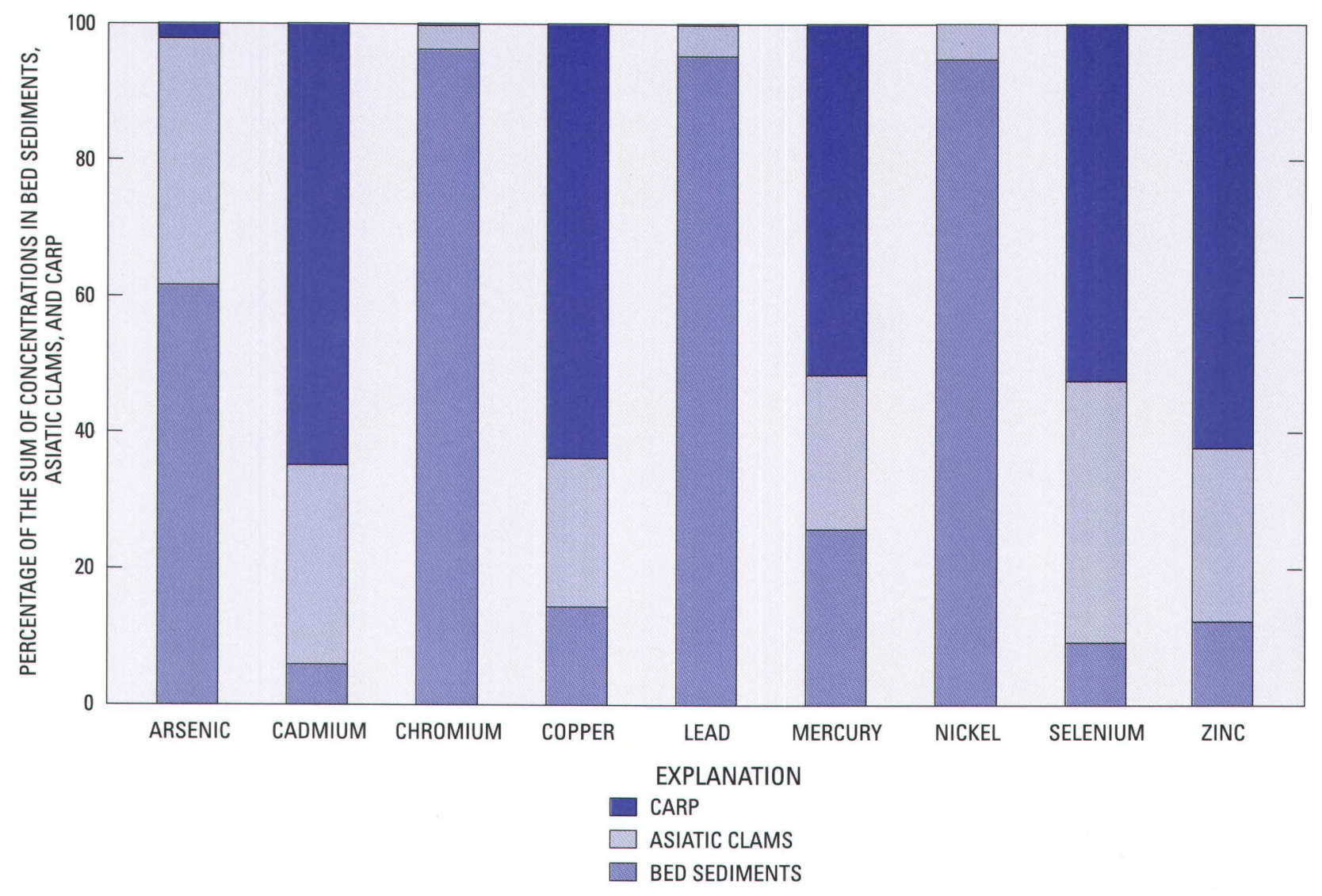

Figure 9. Partitioning of trace-element priority pollutants among bed sediments, Asiatic clams, and carp from six streams in the Santee River Basin and coastal drainages study area. 
weight) of arsenic, chromium, lead, and nickel than were detected in bed sediments (fig. 10). The chemical state of these elements in bed sediments may prevent them from being accumulated by either organism. If so, the source of these elements for clams and carp may be as dissolved form in the water column, leading to uptake at the gill-water interface; adsorbed form on suspended sediments, or as constituents of phytoplankton (food for clams) or macroalgae (food for carp), leading to uptake by ingestion. Alternatively, the elements may be biologically available and taken up from bed sediments by fish and clams, then rapidly depurated.

Within the SANT study area, carp liver tissue contained significantly lower concentrations of arsenic than Asiatic clams. Though clams are regular fare for carp, these data indicate that clams may not have been a source of bioavailable arsenic for the carp (fig. 10).

Within the SANT study area, carp liver tissue contained significantly higher concentrations of cadmium, copper, selenium, and zinc than were detected in bed sediments, and significantly higher concentrations of copper, selenium, and zinc than were detected in Asiatic clams (fig. 11). Since carp regularly consume clams, including Asiatic clams (McMahon, 1991), a biological pathway for copper, selenium, and zinc may exist from clams to carp.

Concentrations of cadmium were not significantly different $(\alpha=0.05)$ between clams and carp (fig. 11). It was not determined for either organism whether ingestion of food or assimilation through the gills by way of the water column is the primary pathway for the accumulation of cadmium. Data on water-column metals concentrations are not available.

Clams accumulated selenium to concentrations significantly higher than those in bed sediments. However, selenium concentrations between clams and bed sediments were not correlated, and this lack of correlation suggests that bed-sediment constituents are not the sources of selenium for clams.
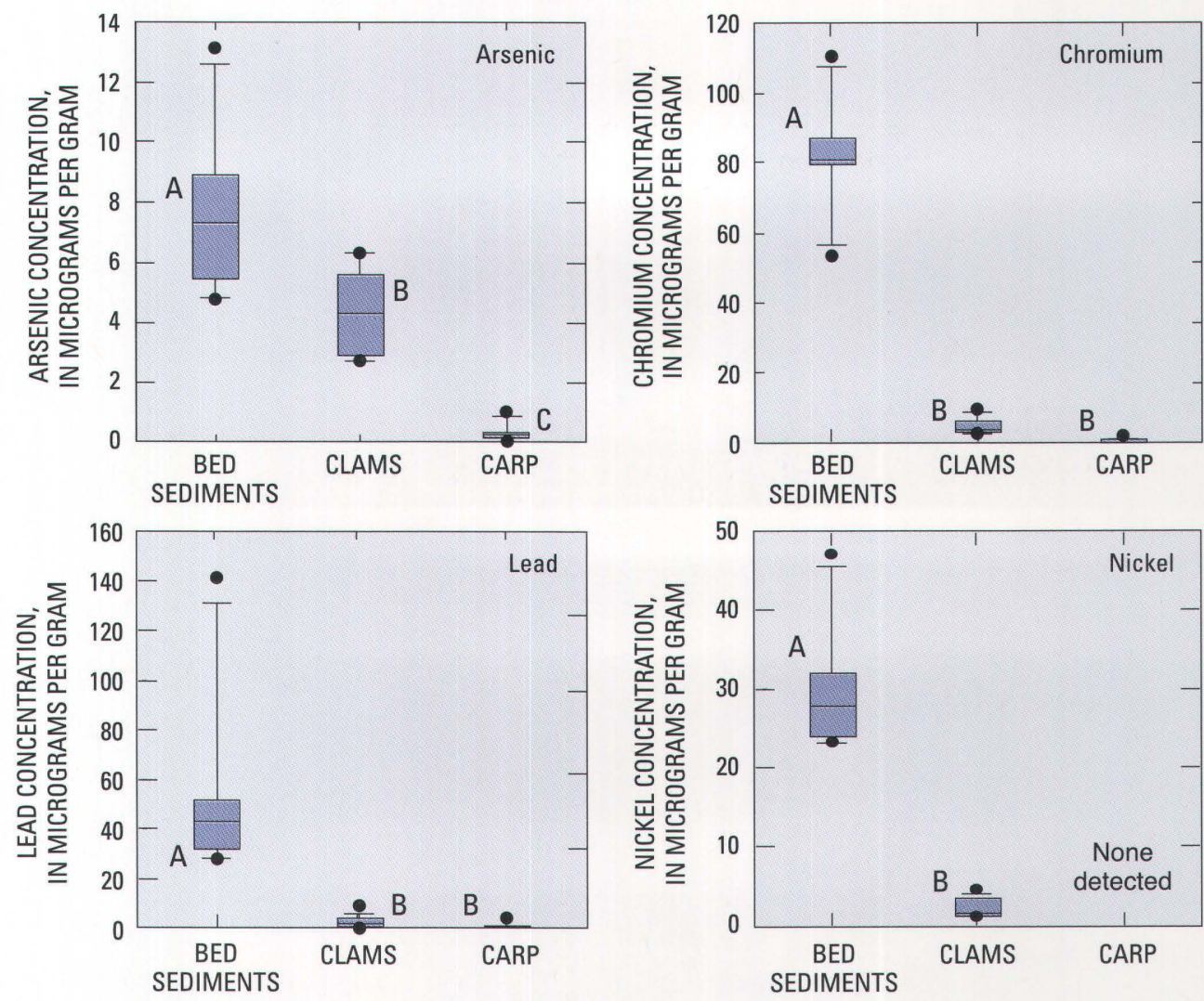

EXPLANATION

- Outlier data value less than or equal to 3 and more than 1.5 times the interquartile range outside the quartile

T $90^{\text {th }}$ percentile

$75^{\text {th }}$ percentile Median $25^{\text {th }}$ percentile

$\perp 10^{\text {th }}$ percentile

Figure 10. Arsenic, chromium, lead, and nickel concentrations among bed sediments, Asiatic clams, and carp. (Boxes with the same letter designation are not significantly different from each other at $\alpha=0.05 ; n=6$ in all cases.) 

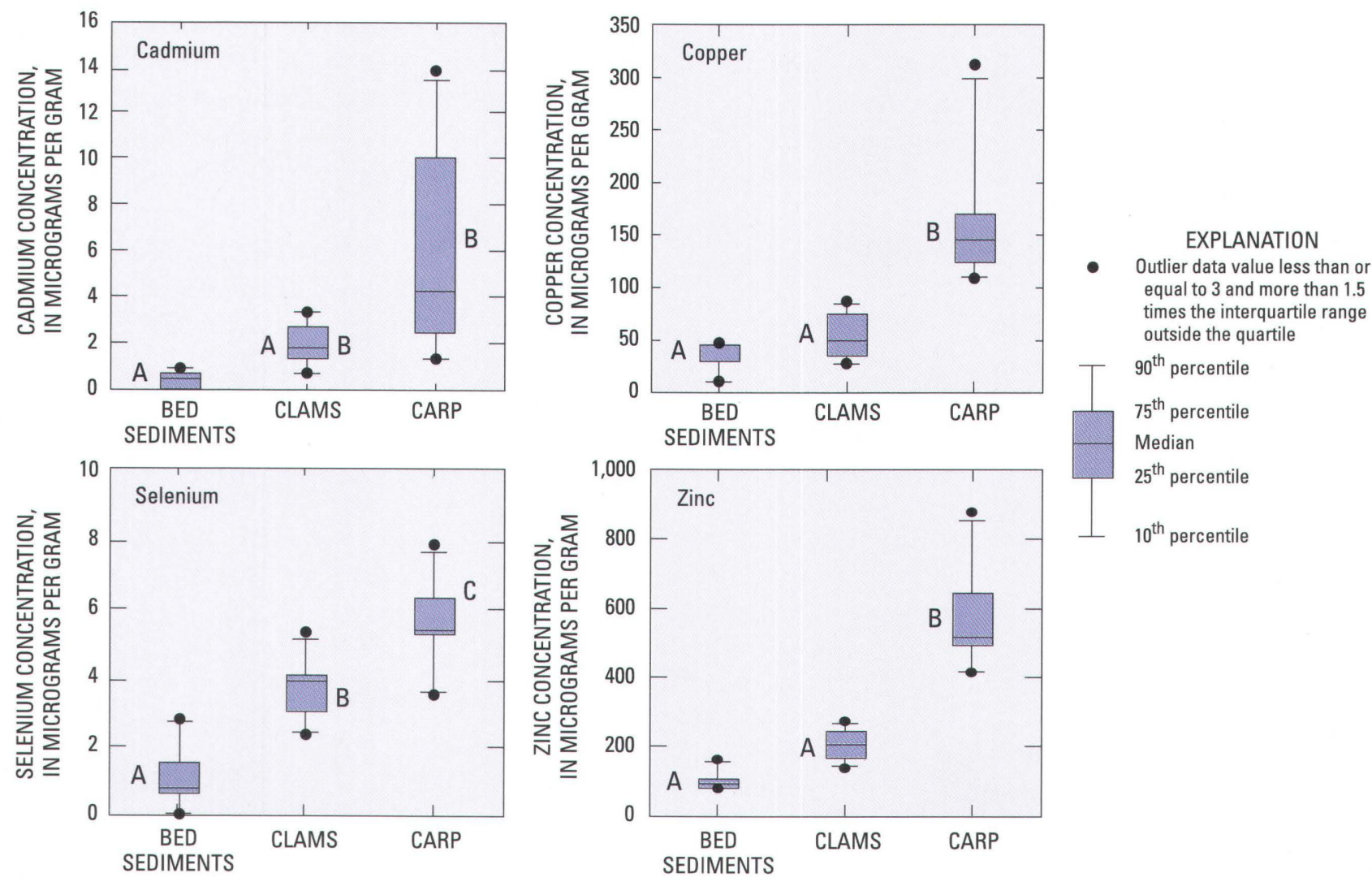

Figure 11. Cadmium, copper, selenium, and zinc concentrations among bed sediments, Asiatic clams, and carp. (Boxes with the same letter designation are not significantly different from each other at $\alpha=0.05 ; n=6$ in all cases.)

Evidence indicates that the most efficient pathway for the bioaccumulation of selenium by clams is through the ingestion of diatoms (Algae, Chrysophyta) rather than direct assimilation from bed sediments (Luoma and others, 1992). Perhaps selenium, complexed with an organic compound in diatoms, is more bioavailable to clams than selenium in bed sediments. The concentration of selenium in carp was not correlated with the concentration of selenium in clams, suggesting that carp accumulate selenium from a source other than clams.

SANT tissue trace-element data are similar to those reported in other NAWQA study areas. In the Red River of the North, for example, Brigham and others (1998) detected higher concentrations of cadmium, copper, selenium, and zinc in carp liver tissue than were detected in bed sediments. Frenzel (1996) reported similar findings for cadmium and selenium in fish in the Central Nebraska Basin. The complete set of SANT bed-sediment and tissue data may be viewed at the SANT NAWQA web site at URL http://wwwsc.er. usgs.gov/nawqa/santhome.html.

\section{MERCURY-A TRACE ELEMENT OF CONCERN}

Fish-consumption advisories have been issued for more than 1,550 miles (mi) of river in South Carolina because popular game fish have been found to contain mercury in concentrations that exceed the State action level for the protection of human health (South Carolina Department of Health and Environmental Control, 1994). South Carolina advisories are issued when the mercury concentration detected in fish filets exceeds $0.5 \mu \mathrm{g} / \mathrm{g}$. The rivers for which the advisories have been issued are primarily those in the Middle Atlantic Coastal Plain ecoregion. Fish-consumption advisories also have been issued for streams in Florida, Georgia, and North Carolina. Florida's advisories include 2,053 mi of waterways, Georgia's advisories 
include 669 mi of the State's waterways, and North Carolina's advisories include 37,600 mi of the State's waterways (U.S. Environmental Protection Agency, 1997).

\section{Mercury in Bed Sediments}

Mercury has a high potential for accumulation by biota and is slow to be depurated by living organisms. Its presence in bed sediments assures contact with sediment-dwelling biota and may be indicative of its existence in the aquatic community.
Results of analyses for mercury in bed sediments are reported as total mercury and are herein referred to as mercury. No attempt was made to discriminate between total mercury and methyl mercury. The median bedsediment mercury concentration in the SANT study area was $0.08 \mu \mathrm{g} / \mathrm{g}$, with the highest concentrations detected in the Coosawhatchie River $(0.25 \mu \mathrm{g} / \mathrm{g})$, the Edisto River, and Gills Creek (each at $0.24 \mu \mathrm{g} / \mathrm{g}$ ). All other streams in the study area had bed-sediment mercury concentrations less than $0.17 \mu \mathrm{g} / \mathrm{g}$. Of the four NAWQA study areas in the Southeast for which data are currently (1999) available, SANT ranked third in bed-sediment median mercury concentration (fig. 12).

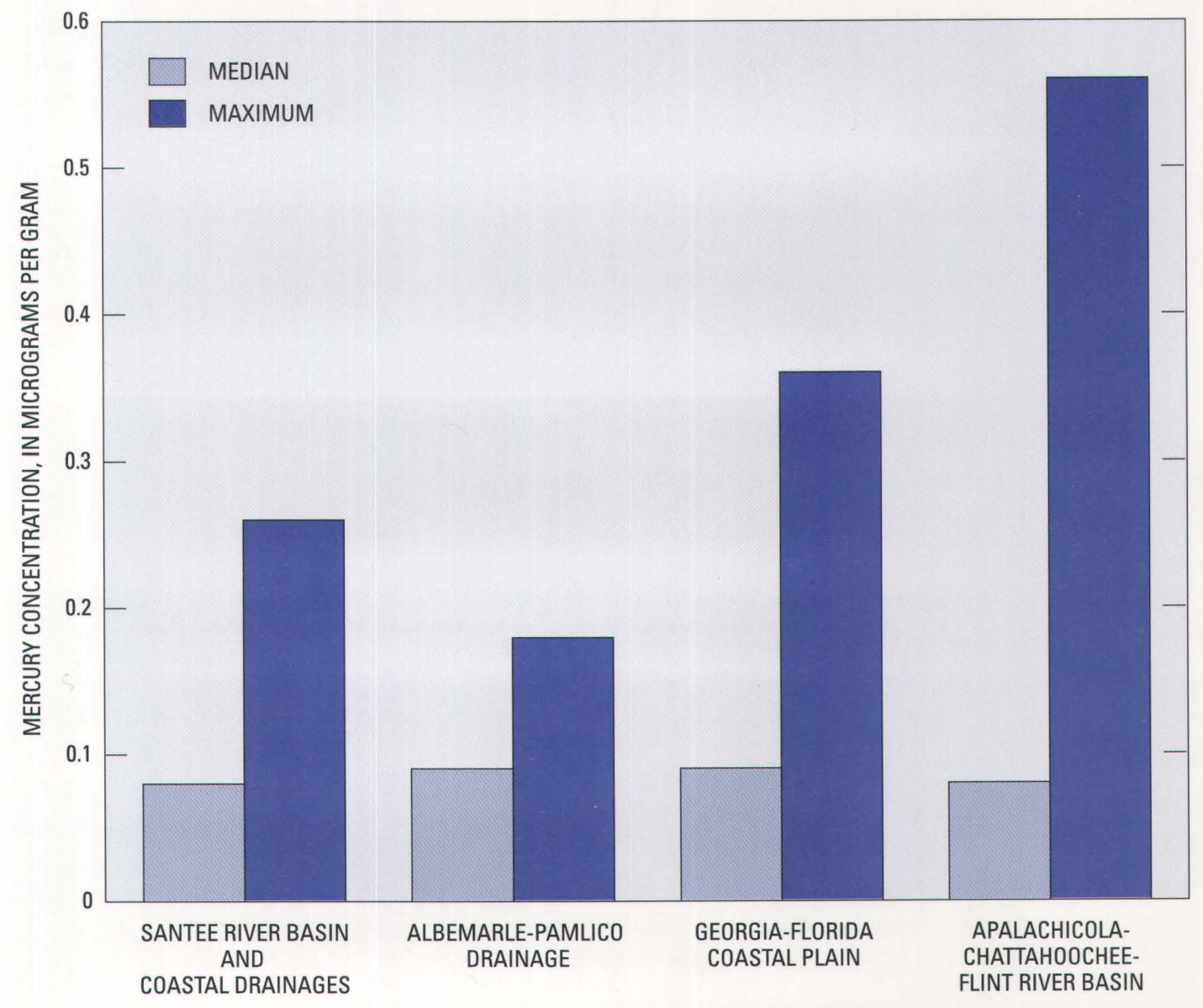

Figure 12. Maximum and median bed-sediment mercury concentrations among southeastern National Water-Quality Assessment Program study areas. 
Comparison of the median mercury concentrations in bed-sediment samples collected in the SANT study area with those of the 1991 NAWQA study areas indicates that mercury is a common element in bed sediments from streams of the contiguous 48 States. Many basins in the country have bed-sediment mercury concentrations similar to or higher than those in the SANT study area (fig. 13).

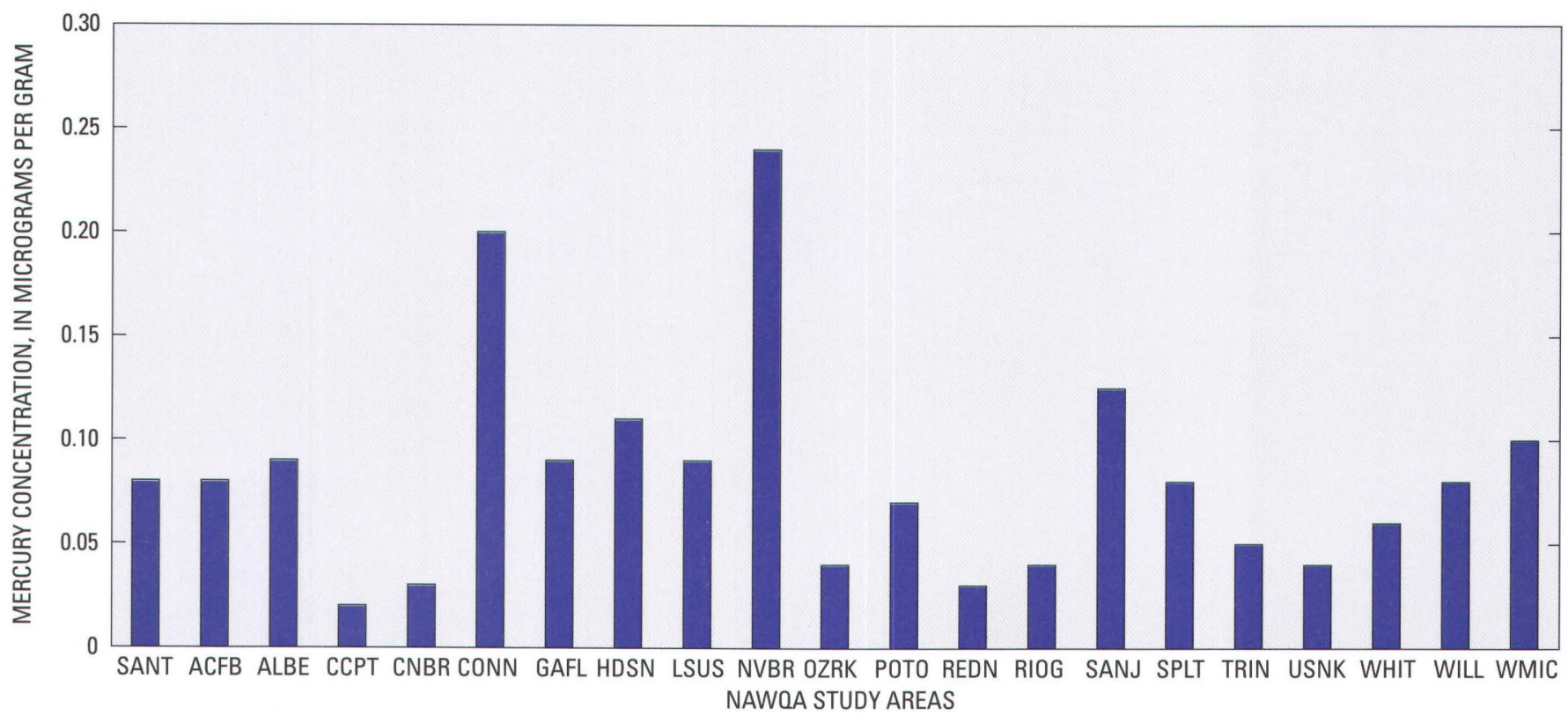

EXPLANATION

SANT Santee River Basin and coastal drainages ACFB Apalachicola-Chattahoochee-Flint River Basin

ALBE Albemarle-Pamlico Drainage

CCPT Central Columbia Plateau

CNBR Central Nebraska Basins

CONN Connecticut, Housatonic, and Thames River Basins

GAFL Georgia-Florida Coastal Plain

HDSN Hudson River Basin

LSUS Lower Susquehanna River Basin

NVBR Nevada Basin and Range

OZRK Ozark Plateaus

POTO Potomac River Basin

REDN Red River of the North

RIOG Rio Grande Valley

SANJ San Joaquin-Tulare Basins

SPLT South Platte River Basin

TRIN Trinity River Basin

USNK Upper Snake River Basin

WHIT White River Basin

WILL Willamette Basin

WMIC Western Lake Michigan Drainage

Figure 13. Santee River Basin and coastal drainages bed-sediment median mercury concentration compared with those of the 1991 National Water-Quality Assessment Program study areas. 


\section{Mercury in Tissue}

Because mercury can accumulate in aquatic organisms, the highest concentrations usually are found in the upper trophic levels (Eisler, 1987). Inorganic (metallic) mercury in bed sediments can be made biologically available through bacterial or fungal conversion to methyl mercury, the most toxic form of mercury in the environment. Ingestion of metallic mercury from bed sediments or particulates in the water column may lead to conversion to methyl mercury inside the body, because enteric microorganisms in some animals may methylate mercury (Laws, 1993). Methyl mercury, soluble in body fats, can be concentrated through sequential trophic levels to concentrations that are significantly higher than those in bed sediments or in the water column (Laws, 1993) and can threaten the health of humans and other consumers of fish.

\section{Mercury in Fish}

The data-collection objectives for this study differ from those of the agencies collecting data that support the issuance of fish-consumption advisories. Consumption advisories are based on data collected in studies of fish likely to be consumed by humans, such as bass, sunfish, and catfish. Fish-tissue analyses for the protection of human health are performed on filets (the most likely part of a fish to be consumed). By contrast, NAWQA protocols require analysis of liver tissue from one or more species in a list of national target taxa that are found over broad regions of the country. The common carp (Cyprinus carpio) was the fish sampled for mercury in the SANT study area. Although the concentration of mercury in carp liver tissue may have no direct relation to the concentration of mercury in the filet of another species of fish, it can, nevertheless, be an indicator of the bioaccumulation of mercury.

In the SANT study area, the concentration of mercury in carp liver tissue ranged from $0.01 \mu \mathrm{g} / \mathrm{g}$ to $4.41 \mu \mathrm{g} / \mathrm{g}$ (Appendix 4). Only concentrations of mercury in carp liver tissue from the Edisto $(4.41 \mu \mathrm{g} / \mathrm{g})$ and Wateree $(0.6 \mu \mathrm{g} / \mathrm{g})$ Rivers exceeded the State action level of $0.5 \mu \mathrm{g} / \mathrm{g}$ (fig. 14). If carp liver tissue were considered comparable to filets, the concentration of mercury in the liver tissue of carp from the Edisto River would have exceeded the State action level by more than eight times.

The higher concentrations of mercury detected in carp from the Edisto and Wateree Rivers are indicative of the bioavailability of the element. The two streams are related in that the ratio of carp liver-to-bedsediment mercury concentrations are very similar,

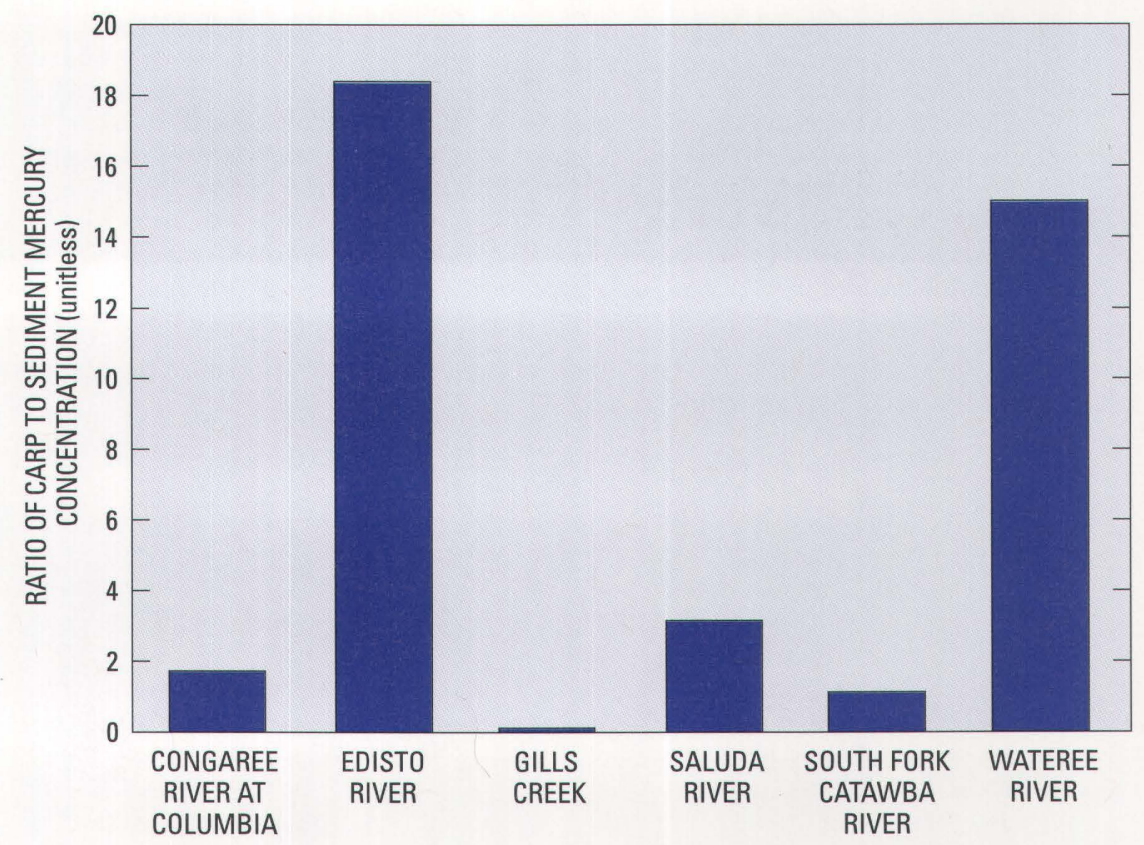

Figure 14. Ratio of carp liver tissue mercury concentration to bed-sediment mercury concentration in six streams of the Santee River Basin and coastal drainages study area. 
suggesting similar mechanisms for the bioaccumulation of mercury in these two rivers (fig. 14). The other four streams from which carp and clam tissue were analyzed were similar to each other but differed from the Wateree and Edisto Rivers in carp-to-bed-sediment mercury ratio (fig. 14). The range of carp-to-bedsediment mercury ratios suggests that more than one mechanism is involved in the transport of mercury through the food web. Carp may take up mercury through direct contact with bed sediments, through ingestion of algae, insects, and clams that have bioaccumulated mercury from the water column or bed sediments, or by direct absorption from the water at the gill-water interface. Benthic invertebrates, such as dragonfly naiads (Odonata), beetle larvae (Coleoptera), stoneflies (Plecoptera), and caddisflies (Trichoptera), are potential bioaccumulators of mercury because they prey on organisms that live in constant contact with bed sediments or they are filter feeders. These invertebrates form a major part of the food web and can pass mercury on to predators, such as carp, sunfish, bass, and catfish.

The accumulation of mercury by fish is a matter of concern to subsistence fishermen and sportsmen. The redbreast sunfish (Lepomis auritus) is the most popular fish species in South Carolina. The next most popular fish are the flat bullhead (Ameiurus platycephalus) and the channel catfish (Ictalurus punctatus) (Barton and O'Brien-White, 1995), both of which are omnivorous and live in close association with the bed sediments of rivers (Rohde and others, 1994). Mercury-containing fish can pose a potential health threat to people who consume them on a regular basis.

Personnel from the South Carolina Department of Health and Environmental Control (DHEC) analyzed filets, skeletal muscle, and whole fish samples from largemouth bass (Micropterus salmoides) collected from the Edisto River several times between 1977 and 1995. The median concentration of mercury in the filets was $1.37 \mu \mathrm{g} / \mathrm{g}(\mathrm{n}=15)$. DHEC personnel also collected sunfish, channel catfish, and bowfins (Amia calva) from the Edisto River. Analyses of filets from bowfin yielded a median mercury concentration of $1.2 \mu \mathrm{g} / \mathrm{g}(\mathrm{n}=6)$. Concentrations of mercury in the skeletal muscles of channel catfish (median $=$ $2.47 \mu \mathrm{g} / \mathrm{g}, \mathrm{n}=3$ ), sunfish (median $=0.7 \mu \mathrm{g} / \mathrm{g}, \mathrm{n}=2$ ), bowfin (median $=0.7 \mu \mathrm{g} / \mathrm{g}, \mathrm{n}=5$ ), and largemouth bass (median $=2.73 \mu \mathrm{g} / \mathrm{g}, \mathrm{n}=3$ ) exceeded the South Carolina action level (David Chestnut, South Carolina Department of Health and Environmental Control, written commun., 1997). The DHEC data are consistent with SANT data showing high levels of mercury in Edisto River carp liver tissue (fig. 15), an indication that mercury is being accumulated by carp in the Edisto River.

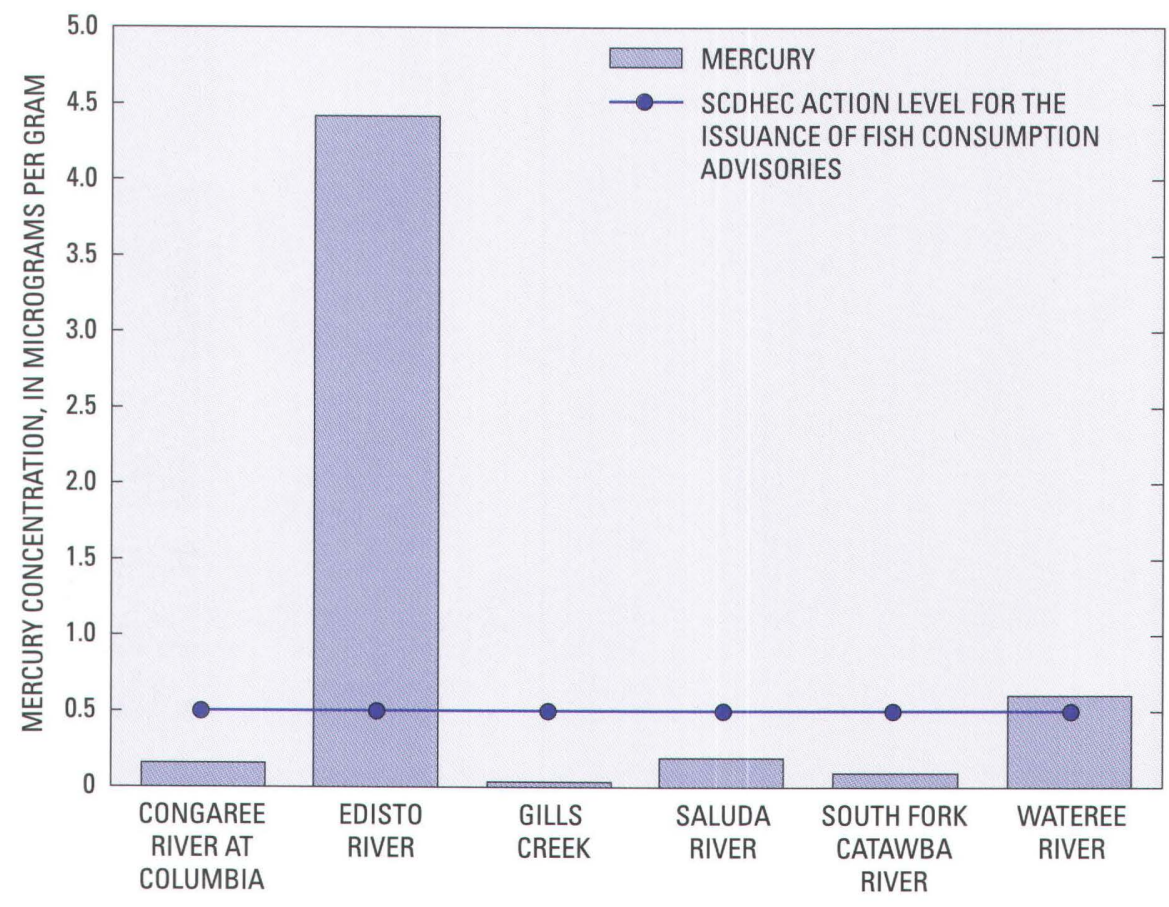

Figure 15. Mercury concentrations in carp liver tissue. 


\section{Mercury in Clams}

Mercury concentrations in Asiatic clams from 3 of the 14 sample sites in streams in South Carolina equaled or exceeded the State action level (fig. 16). Mercury concentrations in Asiatic clams from the Edisto River $(12 \mu \mathrm{g} / \mathrm{g})$ were 24 times the State action level. However, no significant correlation was detected between the concentrations of mercury in bed sediments and clams. Clams may concentrate mercury by ingestion of algae and bacteria rather than by absorption while in close contact with bed sediments. Similarly, among all sites, no correlation was detected between the concentrations of mercury in clams and the concentrations of mercury in carp liver tissue, suggesting that clams may not be the sole source of bioavailable mercury for carp.

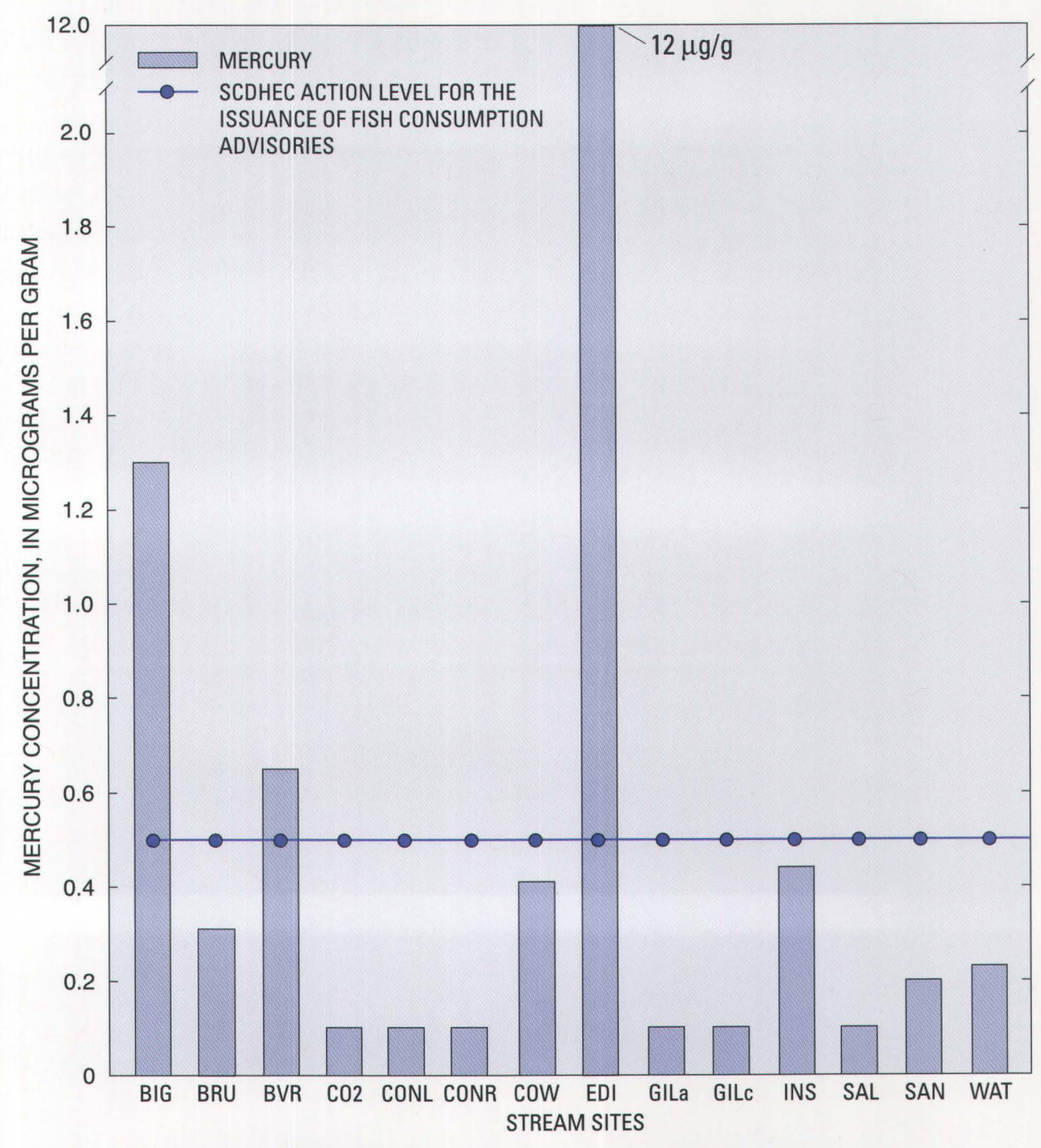

Figure 16. Mercury concentrations in Asiatic clam tissue collected from streams in South Carolina as part of the National Water-Quality Assessment Program. (Site abbreviations are explained in table 1. GILa and GILc are different sections of GIL.) 


\section{CONCLUSIONS}

Analyses of bed-sediment and tissue samples of aquatic organisms collected at selected sites in the Santee River Basin and coastal drainages (SANT) study area, from 1995 to 1997 indicate the following:

- No trace-element priority pollutants in bed sediments from the SANT study area were detected in concentrations considered to be detrimental to aquatic life.

- Bed sediments from streams in urban settings contained significantly higher concentrations of lead than bed sediments from streams in other settings.

- Median bed-sediment concentrations of nine trace-element priority pollutants in the SANT study area are similar to those reported in the 1991 NAWQA study areas.

- Asiatic clams from streams in urban settings contained significantly higher concentrations of copper than those detected in Asiatic clams from streams in other settings.

- Asiatic clams from the Edisto River contained a higher mercury concentration than clams or fish from any other site sampled in the SANT study area.

- Significantly higher concentrations of cadmium, copper, selenium, and zinc were detected in carp liver tissue from the SANT study area than were detected in bed sediments.

- The concentration of mercury in carp liver tissue from the Edisto River was more than eight times the South Carolina action level (which is based on mercury concentrations in fish filets) for the issuance of a fish-consumption advisory.

- Neither Asiatic clams nor carp appear to be bioaccumulating arsenic, chromium, lead, or nickel.

\section{REFERENCES}

Abrahamsen, T.A., Hughes, W.B., Reuber, E.J., and Sicherman, T.L., 1997, Selected aquatic ecology, surface-water quality, and ground-water studies in the Santee River Basin and coastal drainages, North and South Carolina: U.S. Geological Survey Open-File Report 97-115, 49 p.
Annis, C.G., and Belanger, T.V., 1986, Corbicula manilensis, potential bio-indicator of lead and copper pollution: Florida Scientist, v. 49, p. 30.

Barton, M.C., Jr., and O'Brien-White, S.K., 1995, Fishes of the Edisto River Basin, South Carolina: Columbia, South Carolina Department of Natural Resources, $57 \mathrm{p}$.

Brigham, M.E., Goldstein, R.M., and Tornes, L.H., 1998, Trace elements and organic chemicals in stream-bottom sediments and fish tissues, Red River of the North Basin, Minnesota, North Dakota, and South Dakota, 1992-95: U.S. Geological Survey Water-Resources Investigations Report 97-4043, 32 p.

Canadian Council of Ministers of the Environment, 1995, Protocol for the derivation of Canadian sediment quality guidelines for the protection of aquatic life: Report CCME EPC-98E, 38 p.

Code of Federal Regulations, 1996, Title 40 Protection of the Environment, Chapter 1: Environmental Protection Agency, Part 401, Section 401.15, Toxic Pollutants.

Crawford, J.K., and Luoma, S.N., 1993, Guidelines for studies of contaminants in biological tissues for the National Water-Quality Assessment Program: U.S. Geological Survey Open-File Report 92-494, $69 \mathrm{p}$.

Decho, A.W., and Luoma, S.N., 1991, Time-courses in the retention of food material in the bivalves Potamocorbula amurensis and Macoma balthicaSignificance to the absorption of carbon and chromium: Marine Ecology Progress Series, v. 78, p. 303-314.

Eisler, R., 1987, Mercury hazards to fish, wildlife, and invertebrates-A synoptic review: U.S. Fish and Wildlife Service, Biological Report 85 (1.10), 90 p. -1988, Arsenic hazards to fish, wildlife, and invertebrates-A synoptic review: U.S. Fish and Wildlife Service, Biological Report 85 (1.12), 92 p.

Elder, J.F., and Mattraw, H.C., 1984, Accumulation of trace elements, pesticides, and polychlorinated biphenyls in sediments and the clam Corbicula manilensis of the Apalachicola River, Florida: Archives for Environmental Contamination and Toxicology, v. 13, p. 453-469.

Feiss, P.G., Maybin, A.H., III, Riggs, S.R., and Grosz, A.F., 1991, Mineral resources of the Carolinas, in Horton, J.W., and Zullo, V.A., eds., The geology of the Carolinas: Knoxville; University of Tennessee, 406 p.

Fishman, M.J., 1993, Methods of analysis by the U.S. Geological Survey National Water Quality Laboratory-Determination of inorganic and organic constituents in water and fluvial sediments: U.S. Geological Survey Open-File Report 93-125, 217 p. 
Forstner, Ulrich, and Wittmann, G.T.W., 1979, Metal pollution in the aquatic environment: New York, Springer-Verlag, $486 \mathrm{p}$.

Frenzel, S.A., 1996, Occurrence of selected contaminants in water, fish tissue, and streambed sediment in central Nebraska, 1992-95: U.S. Geological Survey Open-File Report 96-223, 6 p.

Goldstein, R.M., Brigham, M.E., and Stauffer, J.C., 1996, Comparison of mercury concentrations in liver, muscle, whole bodies and composites of fish from the Red River of the North: Canadian Journal of Fisheries and Aquatic Sciences, v. 53, p. 244-252.

Hemelraad, J., Herwig, H.J., Holwerda, D.A., and Zandee, D.I., 1985, Accumulation, distribution and localization of cadmium in the freshwater clam Anodonta sp: Marine Environmental Research, v. 17, p. 196.

Hoffman, G.L., 1996, Methods of analysis by the U.S. Geological Survey National Water Quality Laboratory-Preparation procedure for aquatic biological material determined for trace metals: U.S. Geological Survey Open-File Report 96-362, 42 p.

Laws, E.A., 1993, Aquatic pollution: New York, John Wiley \& Sons, Inc., $611 \mathrm{p}$.

Luoma, S.N., and Fisher, N., 1995, Uncertainties in assessing contaminant exposure from sediments-Bioavailability, in Biddenger, G., and Dillon, T., eds., Sediment risk assessment: Asilomar, Calif., Pellston Workshop, 1995.

Luoma, S.N., Johns, C., Fisher, N.S., Steinberg, N.A., Oremland, R.S., and Reinfelter, J., 1992, Determination of selenium bioavailability to a benthic bivalve from particulate and solute pathways: Environmental Science and Technology, v. 26, p. 485.

Maluk, T.L., Reuber, E.J., and Hughes, W.B., 1998, Nutrients in waters of the Santee River Basin and coastal drainages, North and South Carolina, 1973-93: U.S. Geological Survey Water-Resources Investigations Report 97-4172, 60 p.

McMahon, R.F., 1991, Mollusca-Bivalvia, in Thorp, J.H., and Covich, A.P., eds., Ecology and classification of North American freshwater invertebrates: San Diego, Academic Press, Inc., 911 p.

Omernik, J.M., 1987, Ecoregions of the conterminous United States: Annals of the Association of American Geographers, v. 77, no. 1, p. 118-125.
1995, Ecoregions-A spatial framework for environmental management, in Davis, W.S., and Thorpe, P.S., eds., Biological assessment and criteria-Tools for water resource planning and decision making: Boca Raton, Lewis Publishers, 415 p.

Pickett, J.R., 1992, Sources and accumulation of trace metals in sediments and the Asiatic clam, Corbicula fluminea, in two South Carolina watersheds: Columbia, South Carolina Department of Health and Environmental Control, U.S. Geological Survey Award No. 14-08-0001-1735, 93 p.

Price, R.E., and Knight, L.A., Jr., 1978, Mercury, cadmium, lead and arsenic in sediments, plankton and clams from Lake Washington and Sardis Reservoir, Mississippi, October 1975-May 1976: Pesticides Monitoring Journal, v. 11, p. 182-189.

Rice, K.C., 1999, Trace-element concentrations in streambed sediment across the conterminous United States: Environmental Science \& Technology, v. 33, no. 15 , p. 2499-2504.

Rodgers, J.H., Cherry, D.S., Dickson, K.L., and Cairns, John, Jr., 1979, Invasion, population dynamics and elemental accumulation of Corbicula fluminea in the New River at Glen Lyn, Virginia: Proceedings of the First International Corbicula Symposium: Fort Worth, Tex., Oct. 13-15, 1977.

Rohde, F.C., Arndt, R.G., Lindquist, D.G., and Parnell, J.F., 1994, Freshwater fishes of the Carolinas, Virginia, Maryland, and Delaware: Chapel Hill, The University of North Carolina Press, 222 p.

Shelton, L.R., and Capel, P.D., 1994, Guidelines for collecting and processing samples of stream bed sediment for analysis of trace elements and organic contaminants for the National Water-Quality Assessment Program: U.S. Geological Survey OpenFile Report 94-458, 20 p.

South Carolina Department of Health and Environmental Control, 1994, State fish advisory: Columbia, South Carolina Department of Health and Environmental Control [variously paged].

U.S. Environmental Protection Agency, 1997, Listing of fish and wildlife advisories-1997: U.S. Environmental Protection Agency Document No. 823-C-98-001, version 3.0. 
Appendix 1. Land-use percentages for Santee River Basin and coastal drainages National Water-Quality Assessment Program sites

[Values are percentages of basin devoted to the land use. AGR, agricultural; FOR, forested; URB, urban; WAT, open water; WET, wetlands]

\begin{tabular}{|c|c|c|c|c|c|}
\hline \multirow[b]{2}{*}{ Stream } & \multicolumn{5}{|c|}{ Land-use designation } \\
\hline & AGR & FOR & URB & WAT & WET \\
\hline Beaver Creek & 5.68 & 81.08 & 0.00 & 0.09 & 0.42 \\
\hline Big Creek & 25.58 & 70.86 & .01 & .18 & .43 \\
\hline Brushy Creek & 9.71 & 24.09 & 64.72 & .16 & .30 \\
\hline Cedar Creek & 17.93 & 58.20 & 2.03 & 1.67 & 8.14 \\
\hline Cedar Creek near Wise Lake & 23.89 & 51.20 & 2.65 & 1.05 & 15.30 \\
\hline Congaree River at Columbia & 19.83 & 70.11 & 5.09 & 1.90 & .77 \\
\hline Congaree River at Highway 601 & 19.66 & 68.60 & 5.53 & 1.87 & 1.99 \\
\hline Coosawhatchie River & 30.87 & 39.63 & 1.37 & .32 & 23.49 \\
\hline Cow Castle Creek & 46.11 & 39.57 & 94 & .08 & 9.05 \\
\hline Edisto River & 31.92 & 45.16 & 1.48 & .67 & 15.52 \\
\hline Georges Creek & 64.57 & 27.21 & .03 & .37 & .54 \\
\hline Gills Creek & 7.24 & 44.34 & 37.63 & 2.10 & 4.38 \\
\hline Indian Creek, N.C. & 52.99 & 46.00 & .22 & .27 & .37 \\
\hline Indian Creek, S.C. & 7.52 & 86.16 & 1.08 & .10 & .31 \\
\hline Irish Creek & 4.33 & 95.47 & .00 & .03 & .15 \\
\hline Jacob Fork & 1.85 & 96.50 & .28 & .01 & .04 \\
\hline Long Creek & 29.36 & 46.86 & 20.48 & .61 & 1.40 \\
\hline McTier Creek & 19.74 & 72.02 & .15 & .94 & 4.91 \\
\hline Myers Creek & 33.12 & 48.18 & 3.65 & .44 & 14.52 \\
\hline Saluda River & 21.33 & 65.63 & 6.13 & 3.96 & .90 \\
\hline Santee River & 18.75 & 67.82 & 6.43 & 2.12 & 2.69 \\
\hline Shaw Creek & 68.23 & 23.01 & .40 & 3.21 & 5.06 \\
\hline South Fork Catawba River & 30.20 & 59.67 & 8.77 & .32 & .59 \\
\hline Toms Creek & 32.47 & 56.20 & .94 & .98 & 9.30 \\
\hline Wateree River & 17.06 & 69.24 & 8.37 & 2.63 & .91 \\
\hline
\end{tabular}


Appendix 2. Element concentrations in Santee River Basin and coastal drainages bed sediments, and laboratory reporting limits for sediment samples

[SANT, Santee River Basin and coastal drainages; <LRL, less than or equal to the laboratory reporting limit; $\mu \mathrm{g} / \mathrm{g}$, microgram per gram]

\begin{tabular}{|c|c|c|c|c|c|}
\hline \multirow{2}{*}{ Element } & \multirow{2}{*}{ Unit } & \multicolumn{3}{|c|}{ SANT concentrations } & \multirow{2}{*}{$\begin{array}{l}\text { Laboratory } \\
\text { reporting limit* }\end{array}$} \\
\hline & & Minimum & Maximum & Median & \\
\hline Aluminum & percent & 5.3 & 13.0 & 9.35 & 0.005 \\
\hline Antimony & $\mu \mathrm{g} / \mathrm{g}$ & .1 & 2.03 & .50 & .100 \\
\hline Arsenic & $\mu \mathrm{g} / \mathrm{g}$ & 2.6 & 31 & 5.55 & .100 \\
\hline Barium & $\mu \mathrm{g} / \mathrm{g}$ & 220 & 1,600 & 485 & 1.000 \\
\hline Beryllium & $\mu \mathrm{g} / \mathrm{g}$ & 1 & 4 & 3 & 1.000 \\
\hline Cadmium & $\mu \mathrm{g} / \mathrm{g}$ & .1 & .8 & .30 & .100 \\
\hline Calcium & percent & .1 & .73 & .36 & .005 \\
\hline Cerium & $\mu \mathrm{g} / \mathrm{g}$ & 45 & 350 & 135 & 4.000 \\
\hline Chromium & $\mu \mathrm{g} / \mathrm{g}$ & 44 & 150 & 73 & 1.000 \\
\hline Cobalt & $\mu \mathrm{g} / \mathrm{g}$ & 13 & 62 & 22 & 1.000 \\
\hline Copper & $\mu \mathrm{g} / \mathrm{g}$ & 6 & 54 & 31.5 & 1.000 \\
\hline Europium & $\mu \mathrm{g} / \mathrm{g}$ & $<\mathrm{LRL}$ & 4 & $<\mathrm{LRL}$ & 2.000 \\
\hline Gallium & $\mu \mathrm{g} / \mathrm{g}$ & 10 & 33 & 24 & 4.000 \\
\hline Gold & $\mu \mathrm{g} / \mathrm{g}$ & $<\mathrm{LRL}$ & $<\mathrm{LRL}$ & $<\mathrm{LRL}$ & 8.000 \\
\hline Holmium & $\mu \mathrm{g} / \mathrm{g}$ & $<$ LRL & $<\mathrm{LRL}$ & $<\mathrm{LRL}$ & 4.000 \\
\hline Iron & percent & 1.6 & 10 & 4.35 & .005 \\
\hline Lanthanum & $\mu \mathrm{g} / \mathrm{g}$ & 17 & 190 & 68.5 & 2.000 \\
\hline Lead & $\mu \mathrm{g} / \mathrm{g}$ & 13 & 140 & 37.5 & 4.000 \\
\hline Lithium & $\mu \mathrm{g} / \mathrm{g}$ & 20 & 80 & 35 & 2.000 \\
\hline Magnesium & percent & .12 & .67 & .35 & .005 \\
\hline Manganese & $\mu \mathrm{g} / \mathrm{g}$ & 380 & 34,000 & 1,100 & 4.000 \\
\hline Mercury & $\mu \mathrm{g} / \mathrm{g}$ & .03 & .26 & .08 & .020 \\
\hline Molybdenum & $\mu \mathrm{g} / \mathrm{g}$ & $<\mathrm{LRL}$ & 4 & $<\mathrm{LRL}$ & 2.000 \\
\hline Neodymium & $\mu \mathrm{g} / \mathrm{g}$ & 16 & 150 & 57 & 4.000 \\
\hline Nickel & $\mu \mathrm{g} / \mathrm{g}$ & 12 & 78 & 26 & 2.000 \\
\hline Niobium & $\mu \mathrm{g} / \mathrm{g}$ & 10 & 68 & 21 & 4.000 \\
\hline Phosphorus & percent & .04 & .19 & .12 & .005 \\
\hline Potassium & percent & .18 & 2.5 & 1.2 & .050 \\
\hline Scandium & $\mu \mathrm{g} / \mathrm{g}$ & 6 & 21 & 13.5 & 2.000 \\
\hline Selenium & $\mu \mathrm{g} / \mathrm{g}$ & $<\mathrm{LRL}$ & 2.8 & .90 & .100 \\
\hline Silver & $\mu \mathrm{g} / \mathrm{g}$ & .1 & .4 & .20 & .100 \\
\hline Sodium & percent & .04 & .52 & .20 & .005 \\
\hline Strontium & $\mu \mathrm{g} / \mathrm{g}$ & 45 & 320 & 84.5 & 2.000 \\
\hline Sulfur & $\mu \mathrm{g} / \mathrm{g}$ & $<\mathrm{LRL}$ & .22 & .08 & .050 \\
\hline Tantalum & $\mu \mathrm{g} / \mathrm{g}$ & $<$ LRL & $<\mathrm{LRL}$ & $<\mathrm{LRL}$ & 40.000 \\
\hline Thorium & $\mu \mathrm{g} / \mathrm{g}$ & $<\mathrm{LRL}$ & 61 & 21.5 & 4.000 \\
\hline Tin & $\mu \mathrm{g} / \mathrm{g}$ & $<$ LRL & $<\mathrm{LRL}$ & $<\mathrm{LRL}$ & 5.000 \\
\hline Titanium & percent & .4 & 1.1 & .71 & .005 \\
\hline Uranium & $\mu \mathrm{g} / \mathrm{g}$ & 2.3 & 22 & 7.9 & .050 \\
\hline Vanadium & $\mu \mathrm{g} / \mathrm{g}$ & 55.0 & 160 & 110 & 2.000 \\
\hline Ytterbium & $\mu \mathrm{g} / \mathrm{g}$ & 1.0 & 8 & 3 & 1.000 \\
\hline Yttrium & $\mu \mathrm{g} / \mathrm{g}$ & 11.0 & 88 & 30.5 & 2.000 \\
\hline Zinc & $\mu \mathrm{g} / \mathrm{g}$ & 47.0 & 170 & 100 & 4.000 \\
\hline
\end{tabular}

*The LRL controls false negative error. The probability of falsely reporting a non-detection for a sample that contained an analyte at a concentration equal to or greater than the LRL is predicted to be less than or equal to 1 percent. An LRL reported with a "less than" prefix indicates the analyte was not detected in the sample. 
Appendix 3. Element concentrations in Santee River Basin and coastal drainages clam tissue homogenate and laboratory reporting limits for tissue samples

[SANT, Santee River Basin and coastal drainages; ICP-MS, inductively coupled plasma-mass spectrometry; ICP-AES, inductively coupled plasma-atomic emission spectrometry; CV-AAS, cold vapor-atomic absorption spectrophotometry; na, data not available; < LRL, less than the laboratory reporting limit. All concentrations are micrograms per gram dry weight]

\begin{tabular}{|c|c|c|c|c|c|}
\hline \multirow{2}{*}{ Element } & \multicolumn{3}{|c|}{ SANT concentrations } & \multirow{2}{*}{$\begin{array}{c}\text { Laboratory } \\
\text { reporting limit* }\end{array}$} & \multirow{2}{*}{ Method } \\
\hline & Minimum & Maximum & Median & & \\
\hline Aluminum & 14.1 & 7,500 & 480.5 & 1.000 & ICP-MS \\
\hline Arsenic & .2 & 6.4 & 4 & .100 & ICP-MS \\
\hline Barium & .2 & 342 & 45.1 & .100 & ICP-MS \\
\hline Beryllium & $<\mathrm{LRL}$ & 1 & $<\mathrm{LRL}$ & .100 & ICP-MS \\
\hline Boron & .5 & 4.6 & 1.1 & .200 & ICP-MS \\
\hline Cadmium & .6 & 5.1 & 1.5 & .100 & ICP-MS \\
\hline Chromium & 1 & 12.8 & 2.85 & .500 & ICP-MS \\
\hline Cobalt & .4 & 5.9 & 2.4 & .100 & ICP-MS \\
\hline Copper & 1 & 143 & 37.2 & .500 & ICP-MS \\
\hline Iron & 433 & 6,950 & 2,235 & 1.000 & ICP-AES \\
\hline Lead & $<\mathrm{LRL}$ & 22.6 & 2.6 & .100 & ICP-MS \\
\hline Manganese & 10.1 & 5,400 & 156 & .100 & ICP-MS \\
\hline Mercury & .1 & 12 & .245 & na & CV-AAS \\
\hline Molybdenum & $<\mathrm{LRL}$ & 1.5 & 1 & .100 & ICP-MS \\
\hline Nickel & .4 & 6.5 & 2.1 & .100 & ICP-MS \\
\hline Selenium & 1.6 & 7 & 4 & .100 & ICP-MS \\
\hline Silver & .5 & 2.4 & .7 & .100 & ICP-MS \\
\hline Strontium & 1.1 & 134 & 33.5 & .100 & ICP-MS \\
\hline Uranium & $<\mathrm{LRL}$ & 1 & .2 & .100 & ICP-MS \\
\hline Vanadium & $<\mathrm{LRL}$ & 15.2 & 1.35 & .100 & ICP-MS \\
\hline Zinc & 30.7 & 414 & 213.5 & .500 & ICP-MS \\
\hline
\end{tabular}

*The LRL controls false negative error. The probability of falsely reporting a non-detection for a sample that contained an analyte at a concentration equal to or greater than the LRL is predicted to be less than or equal to 1 percent. An LRL reported with a "less than" prefix indicates the analyte was not detected in the sample. 
Appendix 4. Element concentrations in Santee River Basin and coastal drainages carp liver tissue homogenate and laboratory reporting limits for tissue samples

[SANT, Santee River Basin and coastal drainages; ICP-MS, inductively coupled plasma-mass spectrometry; ICP-AES, inductively coupled plasma-atomic emission spectrometry; CV-AAS, cold vapor-atomic absorption spectrophotometry; na, data not available; <LRL, less than laboratory reporting limit. All concentrations are micrograms per gram dry weight]

\begin{tabular}{|c|c|c|c|c|c|}
\hline \multirow{2}{*}{ Element } & \multicolumn{3}{|c|}{ SANT concentrations } & \multirow{2}{*}{$\begin{array}{l}\text { Laboratory } \\
\text { reporting limit* }\end{array}$} & \multirow{2}{*}{ Method } \\
\hline & Minimum & Maximum & Median & & \\
\hline Aluminum & 5.90 & 35.32 & 11.29 & 1.000 & ICP-MS \\
\hline Antimony & $<\mathrm{LRL}$ & $<\mathrm{LRL}$ & $<\mathrm{LRL}$ & .100 & ICP-MS \\
\hline Arsenic & $<\mathrm{LRL}$ & .94 & .27 & .100 & ICP-MS \\
\hline Barium & .12 & .41 & .15 & .100 & ICP-MS \\
\hline Boron & $<$ LRL & .60 & .11 & .200 & ICP-MS \\
\hline Cadmium & 1.17 & 13.84 & 4.17 & .100 & ICP-MS \\
\hline Chromium & $<\mathrm{LRL}$ & .70 & .30 & .500 & ICP-MS \\
\hline Cobalt & $<$ LRL & .3 & .24 & .100 & ICP-MS \\
\hline Copper & 111 & 313 & 145 & .500 & ICP-MS \\
\hline Iron & 379 & 1,430 & 1,100 & 1.000 & ICP-AES \\
\hline Lead & $<\mathrm{LRL}$ & .6 & .11 & .100 & ICP-MS \\
\hline Manganese & 3.72 & 9.22 & 7.02 & .100 & ICP-MS \\
\hline Mercury & .03 & 4.41 & .17 & na & CV-AAS \\
\hline Molybdenum & .68 & 1.36 & 1.03 & .100 & ICP-MS \\
\hline Nickel & $<$ LRL & $<\mathrm{LRL}$ & $<\mathrm{LRL}$ & .100 & ICP-MS \\
\hline Selenium & 3.48 & 7.83 & 5.46 & .100 & ICP-MS \\
\hline Silver & .36 & 2.54 & 1.12 & .100 & ICP-MS \\
\hline Strontium & .37 & .77 & .56 & .100 & ICP-MS \\
\hline Uranium & $<$ LRL & $<$ LRL & < LRL & .100 & ICP-MS \\
\hline Vanadium & .35 & 2.82 & 1.08 & .100 & ICP-MS \\
\hline Zinc & 423 & 899 & 536 & .500 & ICP-MS \\
\hline
\end{tabular}

*The LRL controls false negative error. The probability of falsely reporting a non-detection for a sample that contained an analyte at a concentration equal to or greater than the LRL is predicted to be less than or equal to 1 percent. An LRL reported with a "less than" prefix indicates the analyte was not detected in the sample. 